IZA DP No. 9737

What If Your Boss Is a Woman?

Work Organization, Work-Life Balance and

Gender Discrimination at the Workplace

Claudio Lucifora

Daria Vigani

February 2016 


\title{
What If Your Boss Is a Woman? Work Organization, Work-Life Balance and Gender Discrimination at the Workplace
}

\author{
Claudio Lucifora \\ Università Cattolica del Sacro Cuore \\ and IZA \\ Daria Vigani \\ Università Cattolica del Sacro Cuore
}

Discussion Paper No. 9737

February 2016

IZA

P.O. Box 7240

53072 Bonn

Germany

Phone: +49-228-3894-0

Fax: +49-228-3894-180

E-mail: iza@iza.org

\begin{abstract}
Any opinions expressed here are those of the author(s) and not those of IZA. Research published in this series may include views on policy, but the institute itself takes no institutional policy positions. The IZA research network is committed to the IZA Guiding Principles of Research Integrity.

The Institute for the Study of Labor (IZA) in Bonn is a local and virtual international research center and a place of communication between science, politics and business. IZA is an independent nonprofit organization supported by Deutsche Post Foundation. The center is associated with the University of Bonn and offers a stimulating research environment through its international network, workshops and conferences, data service, project support, research visits and doctoral program. IZA engages in (i) original and internationally competitive research in all fields of labor economics, (ii) development of policy concepts, and (iii) dissemination of research results and concepts to the interested public.
\end{abstract}

IZA Discussion Papers often represent preliminary work and are circulated to encourage discussion. Citation of such a paper should account for its provisional character. A revised version may be available directly from the author. 


\section{ABSTRACT}

\section{What If Your Boss Is a Woman? Work Organization, Work-Life Balance and Gender Discrimination at the Workplace ${ }^{1}$}

In this paper, we investigate the association between female leadership, work organization practices and perceived gender discrimination within firms. Using data for 30 European countries for the period 1995-2010, we find that having a female "boss" is associated with lower overall gender discrimination at work. The female boss effect, however, differs across gender: it is associated with lower discrimination among female employees, but higher among male employees. We also investigate the underlying mechanisms that shape gender discrimination within firms. We find evidence of a "women helping women" pattern through spill-over effects which reduce discrimination among women, but increase discrimination among men, particularly in female-dominated jobs. A better balance between work and life, a supportive work environment and flexible working time, particularly for women in high-skilled jobs, are shown to be effective in reducing gender discrimination. The above findings are robust to a number of specification changes and different sub-populations in our sample. Further, similar results are found when more traditional measures of gender imbalance, such as wages or career prospects, are used. Finally, to account for potential endogeneity and selection, arising from the non-random distribution of females in higher-rank jobs, we jointly estimate the selection process and the discrimination equation, finding support for a causal interpretation of the results.

JEL Classification: J16, J70, J81

Keywords: gender discrimination, female leadership, work organization

Corresponding author:

Daria Vigani

Department of Economics and Finance

Università Cattolica del Sacro Cuore

Largo Gemelli 1

20123 Milan

Italy

E-mail: daria.vigani@unicatt.it

\footnotetext{
${ }^{1}$ We would like to thank Eve Caroli, Lorenzo Cappellari, Maria De Paola, Paul Gregg, Jo Blanden and participants at the conferences "Reducing Inequality" NY City (June 2015), "Inequality and Social Mobility" Rome (September 2015), as well as in seminars held at Università Cattolica del S.C. (2015) and Collegio C.A. (2015) for helpful comments. Daria Vigani acknowledges financial support from UCSC. EWCS data have been kindly provided by Eurofound.
} 
IZA Discussion Paper No. 9737

February 2016

\section{NON-TECHNICAL SUMMARY}

We investigate the association between female leadership, work organization practices and perceived gender discrimination within firms. Using data for 30 European countries for the period 1995-2010, we find that having a female "boss" is associated with lower overall gender discrimination at work. The female boss effect, however, differs across gender: it is associated with lower discrimination among female employees, while discrimination is higher among male employees.

When we investigate the underlying mechanisms that shape gender discrimination within firms, we find evidence of a "women helping women" pattern through spill-over effects which reduce discrimination among women, and increase discrimination among men, particularly in female-dominated jobs. A better balance between work and life, a supportive work environment and flexible working time, particularly for women in high-skilled jobs, are shown to be effective in reducing gender discrimination.

The above findings are robust to a number of specification changes and different subpopulations in our sample. We find similar results when more traditional measures of gender imbalance, such as wages or career prospects, are used. Finally, to account for potential endogeneity and selection, arising from the non-random distribution of females in higher-rank jobs, we jointly estimate the selection process and the discrimination equation, finding support for a causal interpretation of the results.

The implications of the above findings for gender discrimination at work are numerous. First, promoting a higher presence of women in leadership positions, all along the occupational structure, is an effective way of reducing gender bias and discrimination toward women in workplaces. This has a direct (causal) effect, as well as an indirect (spill-over) effect on female subordinates in predominantly female jobs. While there is evidence of an adverse effect on male employees in predominantly female jobs, it is difficult to say whether this is the result of reversal of (taste or statistical) discrimination against women, or a genuine behavioral effect of women discrimination toward men.

Second, our results show that when there is a gender bias in the way work is organized (long working hours, rigid working-time schedules and low work-life balance) women are more likely to be penalized, as compared to men. Thus, promoting family-friendly work practices such as part-time work, flexible working time and parental leave arrangements is another effective way to better balance work and life across gender, particularly for women (and men) with caring responsibilities.

Whether this should be done through company's welfare provided schemes, through public subsidies for part-time work and child care facilities, or both is yet to be assessed. Conversely, any company or public policy that disproportionately rewards long and inflexible working time schedules, either through company bonuses or tax-breaks on overtime work, as well as career concerns that are centered on high work intensity and rank-ordered tournaments are most likely to reduce equality of opportunities for women in organizations. While affirmative action and mandatory quotas for women in executive boards may reverse this pattern, our results suggest that female leadership can have a welfare improving effect on gender discrimination all along the occupational hierarchy. 


\section{Introduction}

Despite the remarkable increase, over the past decades, of female participation in education, labor market and political life, women are still paid less than men and are largely under-represented in supervisory, managerial and executive positions. As reported in a recent study by the European Commission, even if women in Europe account for around 45 per cent of employment and over 55 per cent of people in tertiary education, their proportion in high-level economic decision-making is still very low, as compared to men, with large differences across countries (between 15 and 3 per cent, European Commission, 2012). Empirical studies show that, besides cultural factors, market imperfections and social norms, women segregation in lower layers of the occupational hierarchy also depends on work organization and equal opportunity practices adopted within firms (Bertrand et al., 2014, Goldin, 2014). In particular, when the standards for pay rise, performance-related-pay bonuses and promotions are centered on long working hours, rigid work schedule and seniority, women are less likely to close the wage gap with men and move up the company hierarchy. Conversely, family-friendly work practices such as part-time work, flexible working time and parental leave arrangements make it easier for women with caring responsibilities to balance work and life (OECD, 2007).

Along with the evidence showing the existence of a gender pay gap and the relative under-representation of women in leadership positions, a growing body of literature has investigated the existence of differences in behavioral characteristics across gender (Bertrand, 2011; Niederle, 2014). While the empirical evidence is still controversial, different studies, using both experimental and survey-based methods, have shown that women tend to be less individually oriented and more likely to exhibit a cooperative behavior (Croson and Gneezy, 2009, Fortin, 2008). Women are also generally considered more trust-worthy and oriented toward ethical behavior and integrity (Dollar et al., 2001; Goldin, 2006), they often shy away from competition, are more risk averse and behave more generously when faced with economic decisions (Dohmen et al., 2011, Niederle and Vesterlund, 2007).

These differences in behavior across gender, particularly when considering high ranked and leadership positions, may have important implications in terms of economic and social outcomes within firms. Several contributions in the literature have looked at the effect of gender in top management positions, in terms of management style (Bertrand and Schoar, 2003; Matsa and Miller, 2013) as well as gender composition of the board (Ahern and Dittmar, 2012), on firms' economic and financial performance.

Other studies have explicitly focused attention on the effect of gender, in leadership positions, on wage policies and equal opportunity practices within firms (Flabbi et al. 2014, Fortin, 2008). While there is evidence that the introduction of equal opportunity and equal treatment laws has contributed to reduce gender inequalities in the labor market, the gender gap in both pay and access to high-rank occupations is still remarkable (IMF, 2013, Olivetti and Petrongolo, 2016; Weichselbaumer and Winter-Ebmer, 2007).

One aspect that has been less investigated in the economics literature is the direct 
effect of female leadership and organizational arrangements on gender inequality in firms. Although the relationship between an employee and her supervisor or boss is central to the performance of the firm and the well-being of employees they oversee, still relatively little is known about whether having a female manager or supervisor makes a difference in terms of gender balance and discriminatory behavior at the workplace, and whether that differs for men and women (Artz et al., 2014; Booth and Leigh, 2010; Cardoso and Winter-Ebmer, 2007, Gagliarducci and Paserman, 2015 Lazear et al., 2012, Neumark and Gardecki, 1998).

In this paper, we take a step in this direction and investigate the association between female leadership (i.e. having a female "boss"), work organization practices and perceived gender discrimination, reported by employees within firms. We contribute to different strands of the literature. First, to the literature on discrimination which has mainly used indirect measures - such as gender differentials in wages, call-back rates, promotions, etc. -, while we rely on a direct measure of perceived gender discrimination, experienced and reported by the individuals at the workplace. Second, to the literature on the effect of leadership on employees' outcomes, investigating the effects of female leadership on gender discrimination at work, which we match with work organization and work-life balance arrangements to assess whether familyfriendly work practices play a role. Third, we complement existing evidence from laboratory or field experiments on the behavioral determinants of gender discrimination, using survey-based evidence on a large number of countries and over a long span of time. Finally, we address the potential endogeneity and selection arising from the non-random distribution of females, across jobs and occupations, explicitly modeling the selection process for accessing supervisory and managerial positions jointly with the probability of reporting discrimination.

The paper is organized as follows. In section 2 we review the evidence on the links between female leadership, work organization arrangements and discrimination at the workplace. Section 3 describes the data and the main variables of interest. Section 4 presents the empirical strategy and our baseline results. In section 5, we delve deeper into the mechanisms that are at work in shaping the relationship between female leadership and gender discrimination, testing several behavioral hypotheses. Section 6 and 7 address selection issues and present a number of robustness checks. In section 8 we discuss the main implications of our findings for firms and for public policy.

\section{Female leadership, work organization and gender dis- crimination}

There are several reasons why female leadership may have an effect on gender inequalities within firms. First, if wage determination and career advancements are affected by taste-discriminatory behavior of (mainly male) supervisors and managers, a larger representation of women at the top of the occupational hierarchy is expected 
to reduce the gender wage gap and provide more opportunities (for women) to be promoted (Albrecht et al., 2003, Becker, 1957). Second, it has been argued that under imperfect information female managers might be better at inferring other women unobserved productivity, hence reducing statistical discrimination toward women (Aigner and Cain, 1977). In this respect, females are likely to receive higher wages when employed by a female manager rather than by a male, while lower wages are likely to be paid to males by female managers. Third, on top of the effect on wages, female leadership may be expected to adopt a management style that is less biased toward women, introducing family-friendly policies and balanced work-life practices. However, while this is expected to be beneficial for women and their well-being, it is less obvious what the effects on men would be. Fourth, behavioral differences across gender - i.e. risk aversion, competitive attitude and gender identity - may affect the way women behave in predominantly male work environments, as opposed to women who are in predominantly female jobs. Finally, quite independently from gender attributes, work practices and pay policies within firms can influence both the share and the distribution of women in the occupational hierarchy as well as the gender wage gap.

The above propositions have been extensively investigated in a number of papers, which have focused on specific segments of the labor market and on selected countries, reporting mixed evidence. Cardoso and Winter-Ebmer (2007) find evidence, for Portugal, that female executives, compared to male executives, increase women's wages within firms, while they lower men's wages. Bell (2005) investigates the gender pay gap in executive positions in US firms and shows that the magnitude of the gender pay gap is statistically related to the gender of the CEO, such that female executives are found to promote more women and pay them more as compared to male executives.

A recent study, by Flabbi et al. (2014), looks at the effect of female leadership, among Italian CEO, on the entire distribution of wages. Their findings show that females at the top (bottom) of the wage distribution receive higher (lower) wages when employed in a firm led by a female CEO; while the opposite holds for men (i.e. lower wages at the top and higher at the bottom). The idea is that female leadership is able to reverse statistical discrimination against women, but the side effect is a similar distortion on men's wages. Another interesting implication is that a change from male to female leadership reduces gender pay inequalities at the top of the distribution and increases them at the bottom, while there is virtually no effects on the average wage. These findings have been challenged in a paper by Gagliarducci and Paserman (2015), who study the effect of the gender composition of top managers in Germany on workplace arrangements and pay. They find no statistically significant effect of female leadership, or the share of women in high-rank occupations, on the gender wage gap. A similar result is found by Bertrand et al. (2014), in the context of Norwegian firms, who find no effect of female board members on the overall gender wage gap. 
Experimental and field studies have focused more on the role of behavioral traits. Women are shown to be more likely to enter competitive settings if surrounded by other women rather than men (Niederle and Vesterlund, 2007). Also women applying to predominantly male jobs seem to experience lower levels of discrimination as compared to men applying to predominantly female jobs (Niederle, 2014). There is also evidence of a so-called "Queen bee syndrome" whereby women who have reached the top ranks of the occupational hierarchy, particularly in male dominated occupations, often hinder the career progression of other females (Bagues et al., 2014).

While, as discussed above, female leadership is expected to organize work in a way that is less gender biased and more family-friendly, evidence in this respect is scarce and rather controversial. Results show that the effect of female leadership is heterogeneous and depends on a number of factors, such as: the gender composition of lower layers within the organization, whether the occupation considered is predominantly male or female and how pay incentives are designed. Greater female representation at higher ranks is found to generate positive spillovers on women's career advancements in Norway (Kunze and Miller, 2014) and in promoting female representation among directors and executives in the US: a pattern that has been called "women helping women" (Matsa and Miller, 2013). In an analysis of the propensity to hire and retain females among athletic directors, Bednar and Gicheva (2014), find instead no evidence that gender is strongly predictive of a supervisor's female-friendliness.

The general idea behind the "women helping women" hypothesis is that spillovers from female bosses are assumed to be effective in reducing gender imbalances, which is what justifies public policies to promote female leadership (such as affirmative action and quotas). However, as shown in the empirical literature, spillovers from (female) bosses are likely to be very heterogeneous according to the gender of the subordinate, the share of females in the occupation and other workplace attributes. Although the evidence from existing studies is mixed, the main findings suggest that female bosses are more likely to promote women and pay them more, as compared to male bosses, which should reduce gender inequalities and discrimination against females. Spillover effects often work in opposite direction when the subordinate is a male, so that men may lose out when their boss is female rather than male Cardoso and Winter-Ebmer, 2007; Flabbi et al. 2014). Moreover, these effects are likely to differ in predominantly female (male) jobs, due to behavioral differences across gender - such as risk aversion, competitive attitude and gender identity -, as well as to composition effects, since it is more difficult to promote a woman when female employees are the majority in a given layer of the occupational hierarchy. Female leadership can also have negative spillovers on gender discrimination, when for example women in managerial or supervisory positions use their discretionary power to prevent other women from receiving pay bonuses or progressing in the occupational hierarchy (Bagues et al., 2014).

Finally, female leadership and a higher share of women in the firm are also fre- 
quently associated with a more favorable work environment in terms of time flexibility and work-life balance practices, with beneficial effects on wage inequalities and gender balance in occupational attainment. Of course, working time flexibility, while being of great value for women, may also entail a cost for the firm. Most of the studies that have investigated the effects of female leadership on gender inequality have mainly focused on the patterns between occupations, for example analyzing how female CEO and women in executive positions affect the gender pay gap or the promotion opportunities of male and female employees within firms (Cardoso and Winter-Ebmer, 2007; Flabbi et al., 2014), as well as asking why females tend to be segregated in selected occupations (Barbulescu and Bidwell, 2013; Bertrand et al., 2014). However, since a large part of gender inequalities and discrimination take place within occupations, the above explanations miss an important part of the story ${ }^{2}$.

The traditional view has always claimed that work-life balance practices are amenities introduced in organizations at the expense of efficiency, such that pay levels in more favorable work environment are expected to be lower. Hence, compensating differentials should explain why there is a gender pay gap within firms, and why women tend to be concentrated in selected occupations. In particular, much of the existing gender gap in firms appears to be due to how firms select, reward and organize the work of their employees who have different preferences in terms of time flexibility and work-life arrangements (Goldin, 2014, Goldin and Katz, 2012).

In a recent paper, Goldin (2014) shows that occupations where work is organized around long working hours, inflexible work schedules and where employees are not easily substitutable, pay and promotion probabilities exhibit non-linearities that disproportionately benefit those employees (mostly men) who are able (or prefer) to work under tight constraints, thus increasing gender inequalities. This is likely to be observed in high-rank/high-pay occupations, involving high commitment and effort, in occupations selecting employees through highly competitive rank-ordered tournaments, that disproportionately reward winners, as well as where the organization of work is rather inflexible. In such occupations the penalty attached to time flexibility and other job-related amenities is very large and affects mostly women. Conversely, in jobs where work is organized around more standardized tasks and flexible time schedules, where responsibilities are more evenly shared among employees and parttime work is more diffused, gender differences in pay and promotion are likely to be less pronounced (Bloom et al., 2009, Datta Gupta and Eriksson, 2012, Kato and Kodama, 2015).

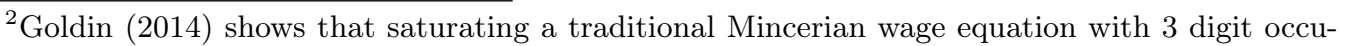
pational dummies, or weighting equally male and females across occupations, the residual gender pay inequality is reduced by less than $1 / 3$, meaning that the other $2 / 3$ depend on other factors. A relevant part of the residual gender inequality is shown to be related to how the work is organized and rewarded in firms, and how the tasks and responsibilities are allocated across gender.
} 


\section{Data and descriptive statistics}

\subsection{Sample selection and variables description}

We use four waves (1995, 2000, 2005 and 2010) of the European Working Conditions Survey (EWCS), a unique source of data combining a large coverage of countries (EU28 plus Turkey and Norway) 3 , with detailed information on employees demographics, job attributes, working conditions and indicators of self-reported satisfaction, health and discrimination at the workplace. The survey is also very rich in terms of management and work organization arrangements (Eurofound, 2012). Our sample includes workers, aged 15 to 65 , employed in the non-agricultural sector 4 . Overall, our final sample consists of 63,318 observations.

Gender discrimination in our dataset is assessed asking respondents to answer the following question: "Over the past 12 months, have you been subjected at work to discrimination on the basis of your sex?". Hence, what we observe are specific episodes of discrimination as perceived and reported by employees, likely to reflect: either a missed promotion or pay increase which was granted to a co-worker of the opposite sex, or a bias in the allocation of tasks across gender. Notice that both the wording of the question, as well as the recall time limit, may induce reporting bias in our measure of discrimination, such that for employees may be more likely to report direct discrimination episodes occurred at the workplace, neglecting other forms of hidden discrimination and occupational segregation. In our sample, around $2 \%$ of respondents reported to have been subjected to gender discrimination, this share goes up to $3 \%$ when we look at women only, conversely the share of men reporting gender discrimination is much lower.

Since measures of direct discrimination are not common in the literature and are open to criticism for being sensitive to individual judgment, as well as to variations in the work environment, we also replicate the analysis using more standard variables such as earnings and career advancements. The earnings variable we use is defined as net monthly earnings, while for career advancements we rely on a specific question about employees' expectations over career prospects in the current job 5 . Since both variables are available only in the 2010 survey, the analysis on earnings and career advancement is restricted to the last wave of EWCS data.

Female leadership is measured through the question "Is your immediate boss a man or a woman?". Respondents whose immediate "boss" is a woman account for $24,4 \%$ of the sample, and over $3 / 4$ of employees with a female boss are women. The share of female bosses has been growing over time, it was $21 \%$ in the 1995 wave and

\footnotetext{
${ }^{3}$ Belgium, Denmark, Germany, Greece, Spain, France, Ireland, Italy, Luxembourg, Netherlands, Austria, Portugal, Finland, Sweden and UK are present in each wave, while Norway, Bulgaria, Czech Republic, Estonia, Latvia, Lithuania, Hungary, Poland, Romania, Slovenia, Slovakia, Croatia, Malta, Cyprus and Turkey entered the survey in 2005. The whole empirical analysis is carried out using either country level post-stratification weight or cross-national weights (Eurofound, 2010)

${ }^{4}$ Retired individuals, students in full-time education, self-employed and employees in the armed force have been excluded. We also set to missing all observations in which the respondent replied "Don't Know" or "Refusal".

${ }^{5}$ The exact wording of the question is, "my job offers good prospects for career advancement" and respondents have to agree or disagree (on a 5-point scale, from strongly agree to strongly disagree) with the statement. We recoded the variable as a dummy taking value one if the respondent agrees or strongly agrees and zero otherwise.
} 
$27 \%$ in 2010 . It is worth noting that the above definition of female leadership differs, in several ways, from the definition used in most studies in the literature. First, it is directly reported by the worker and not indirectly inferred from occupational classifications or other external information, which in our case should reduce measurement error and missclassifications. Second, the definition of female boss encompasses any leadership position along the whole hierarchical structure and not just female CEO or other executive positions. In this respect, while women who have reached the very top of the organizational hierarchy can certainly make a difference in contrasting discrimination within firms and promoting more family-friendly work environment, it is probably true that the immediate boss (whether manager or supervisor) is what matters most for gender imbalances and discriminatory behaviors at the workplace in terms of allocation of workloads, discretionary pay increase and career advancements.

In the empirical analysis we include a large set of controls capturing individual, firm and job characteristics. Managerial policies and work organization practices, which may be relevant for gender inequalities within firms (such as, work-life balance, flexible working time and other family-friendly arrangements), have been grouped into 3 broad areas: work intensity (job involves working at high speed or tight deadlines; having enough time to get the job done), time flexibility (working more than 40 hours a week/10 hours a day at least once a month; having the chance to take a break when wished), and work environment (receiving support from colleagues; able to balance work and life). Further information on other working conditions and social activities in which respondents are involved outside work are used to carry out robustness and sensitivity analyses. The full list of variables used and their means are reported in Table A1 in the Appendix.

While the information available in EWCS data are ideal to exploit the wide differences in management, work organization and other institutional arrangements across European workplaces, there are also some obvious limitations. Two in particular are worth mentioning: first, data are not drawn from an employer-employee survey, which makes impossible to identify employees that work in the same firm and account for their common unobserved characteristics; second, data do not allow to follow the same individual over time and thus account for individual time invariant unobserved heterogeneity. The trade-off, with respect to some existing studies which use employer-employee panel data drawn from administrative data, is that those studies (with few exceptions) have to rely on more limited or imprecise information on work practices and firms' attributes, and generally focus on a single country ${ }^{6}$. In our data, the availability of detailed information on employees' work tasks, firm's

$6 \overline{\text { Cardoso and Winter-Ebmer (2007) }}$ use administrative data from the Ministry of Employment in Portugal; Flabbi et al. (2014) match the Italian social security archive with two company surveys; Bertrand et al. (2014) used data from the Norwegian Registry Archives merged with the Register of Business Enterprises and the Register of Company Accounts. Datta Gupta and Eriksson (2012) and Gagliarducci and Paserman (2015) are able to match their employer-employee panel data (the first from Statistic Denmark, the second from IAB and social security data for Germany) with ad-hoc workplace surveys with information on management and work organization practices similar to our own. Kato and Kodama (2015) use firm-level data from Japan. 
attributes and work organization practices, allows us also to investigate the mechanisms through which female leadership and family-friendly arrangements are related to gender discrimination, without relegating them to fixed effects. Moreover, the coverage of up to 30 European countries for nearly two decades, constitutes a clear advantage in terms of generalizability and external validity of our results Bloom et al. 2009).

\subsection{Descriptive statistics}

Summary statistics for our main variables of interest are reported in Table 1.We compare jobs where the boss is a woman with jobs where the boss is a man. Aggregate figures show that leadership is polarized by gender: jobs where female employees are the majority are more likely to have a woman as a boss (78\%), while the opposite occurs among male employees (66.6\%).

Table 1 - Descriptive statistics: female leadership, job and firm characteristics

\begin{tabular}{lcclcc}
\hline & $\begin{array}{c}\text { Boss } \\
\text { man }\end{array}$ & $\begin{array}{c}\text { Boss } \\
\text { woman }\end{array}$ & & $\begin{array}{c}\text { Boss } \\
\text { man }\end{array}$ & $\begin{array}{c}\text { Boss } \\
\text { woman }\end{array}$ \\
\hline $\begin{array}{l}\text { Demographics } \\
\text { male }\end{array}$ & 66.65 & 21.90 & $\begin{array}{l}\text { Job and Firm } \\
\text { private sector }\end{array}$ & 76.33 & 57.40 \\
female & 33.35 & 78.10 & small firm <100 & 68.11 & 69.74 \\
& & & & & \\
Age & & & Work organization & & \\
$<25$ & 11.20 & 11.08 & pace of work & 63.22 & 56.81 \\
$25-35$ & 29.73 & 29.66 & enough time & 84.58 & 84.37 \\
$36-55$ & 51.32 & 50.86 & long hours & 38.79 & 27.87 \\
$>55$ & 7.75 & 8.39 & breaks at work & 60.12 & 54.12 \\
& & & colleagues support & 89.91 & 89.76 \\
Education & & & work-life balance & 66.50 & 72.62 \\
compulsory & 14.07 & 10.56 & Gender discrimination & & \\
secondary & 51.94 & 49.81 & females & 3.70 & 1.98 \\
tertiary & 33.99 & 39.63 & males & 0.54 & 1.34 \\
\hline Total & & & & 75.6 & 24.4 \\
N & & & & 47,890 & 15,427 \\
\hline
\end{tabular}

Note: The figures reported in the table are percentages.

Female bosses are more diffused in private sector jobs, while no remarkable differences are found by age, education or firm size. Female leadership is also more concentrated where working long hours is less common (i.e. above 40 hours worked in a week, and more than 10 hours worked in a day), and where the overall organization of work is more family-friendly (i.e. less intensive pace of work and better work-life balance arrangements). Notice that the higher concentration of family-friendly work environments and a higher share of women in jobs with a female boss suggest the existence of sorting by gender across jobs and workplaces on the basis of firms' attributes and work organization practices ${ }^{7}$

\footnotetext{
${ }^{7}$ Looking at gender differences in job attributes, part-time appears to be more common among female employees $(25.7 \%$ as opposed to $5 \%$ among male), net earnings are higher for men (the average gender pay gap for 2010 is $23 \%$ ) and a larger fraction of male employees reports expecting good career prospects ( $34 \%$ as opposed to less than $30 \%$ of women).
} 
Gender discrimination also shows a lower incidence among female employees when the immediate boss is a woman ( $2 \%$ for females, $1.3 \%$ for males), while the opposite occurs in jobs with a male boss ( $4 \%$ for females, less than $1 \%$ for males).

Below we further inspect the association between gender discrimination and the share of females in selected occupations. In Figure 1 we plot the share of female employees in the job (left panel) and the share of bosses who are women (right panel) against gender discrimination (separately for males and females). The figure shows that gender discrimination perceived by female (male) employees is highest in predominantly male (female) occupations and it decreases as the share of women increases (decreases). A similar pattern is found when the share of female bosses in the occupation is considered, showing that discrimination among women decreases also when the share of female bosses increases, while the opposite holds for males.

Figure 1 Gender discrimination, female share and share of female bosses by occupation

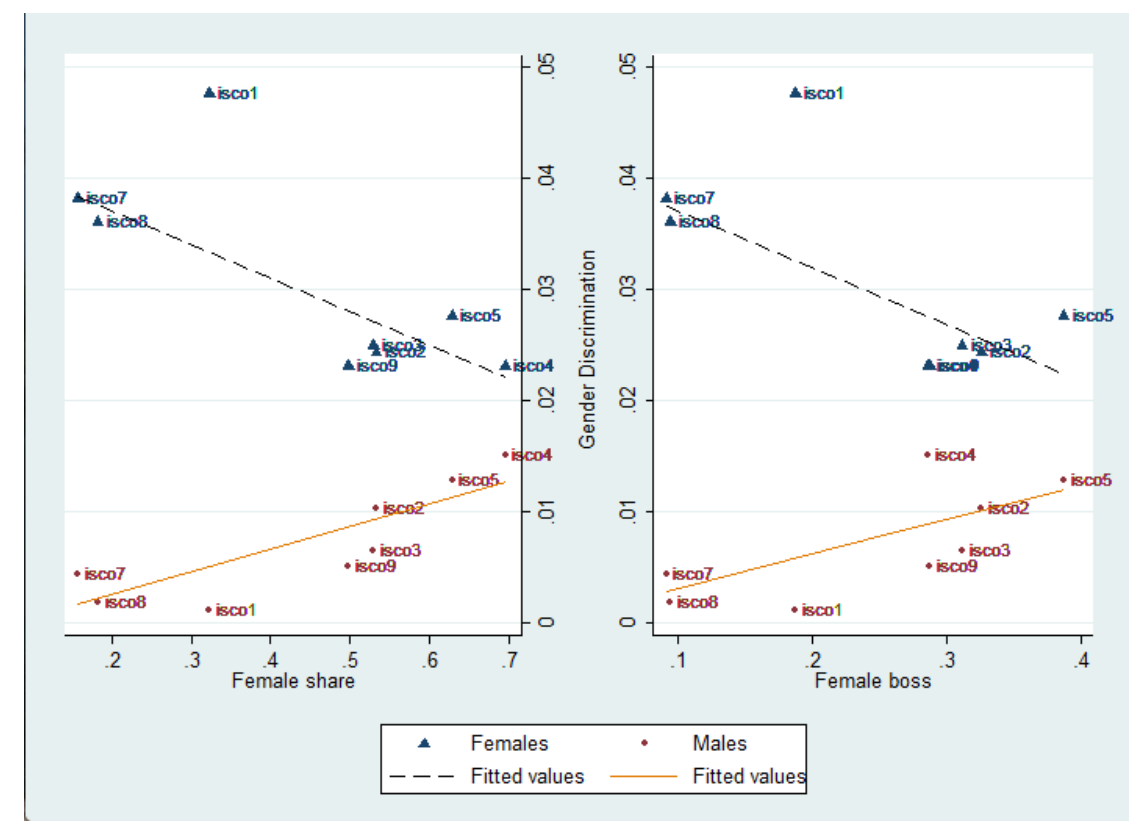

The similarity of trends with respect to gender discrimination between the share of female employees in the job and the share of female bosses are also indicative of a pattern where the presence of a woman as immediate boss is associated to a larger share of females in the occupation and a lower gender discrimination for women, but higher for men.

\section{Empirical analysis: does having a female "boss" make a difference?}

To investigate the relationship between female leadership and perceived gender discrimination, we estimate a probability model where discrimination is a binary outcome and having a woman as immediate boss is our variable of interest. Since, as shown in the descriptive analysis, female leadership is more likely to be found in jobs where women are over-represented and the organization of work is more family- 
friendly, we always control for the share of female employees in the job, as well as a number of work organization attributes. In practice, our baseline model is specified as follows:

$$
\begin{aligned}
\operatorname{Pr}_{\left(\text {Discr }_{i j t}=1\right)} & =\phi\left(\alpha+\gamma \text { bosswoman }_{i j t}+\delta \text { femaleshare }_{i j t}+\beta_{1} \text { WO }_{i j t}+\right. \\
& \left.+\beta_{2} X_{i j t}+c_{j}+t_{t}+\varepsilon_{i j t}\right)
\end{aligned}
$$

where $D_{i s c r_{i j t}}$ is a latent dummy variable that takes value 1 if individual $i$, in country $j$ at time $t$ experienced and reported gender discrimination at the workplace. The variable bosswoman $_{i j t}$ is a binary indicator that takes value 1 when the employee has a woman as immediate boss, while femaleshare fijt $_{\text {in }}$ the share of female employees in the jol" $W_{i j t}$ is a set of work organization variables that describe employees' work intensity (working at high speed or tight deadlines, not-having enough time to get the job done), working time flexibility (working more than 40 hours a week/more than 10 hours a day, taking a break when wished), and whether there is a good work environment (work-life balance and receiving support from colleagues). Finally, $X_{i j t}$ is a set of covariates, controlling for demographics (gender, age groups, educational attainment and marital status), job-related attributes (occupational dummies at 2digit ISCO-88 and tenure) and other firm characteristics (industry dummies at 2-digit NACE, log of firm's size and public sector). All specifications also include country $\left(c_{j}\right)$ and time fixed effects $\left(t_{t}\right)$.

Equation (1) is estimated as a simple probit on the pooled sample, as well as separately for females and males. In the robustness analysis we experiment further specifications where we include additional controls for the work environment (employees' satisfaction with working conditions, job security, favorable work environment and having friends at work), as well as information on individual attitudes (risk aversion ${ }^{9}$ ), and social preferences (activities outside work). We also replicate the analysis replacing our direct measure of perceived discrimination with more traditional variables used in the gender discrimination literature, such as earnings and career advancements.

One additional fundamental problem in estimating equation (1) is that the presence of women in higher rank of the occupational hierarchy (i.e. supervisory and managerial positions) within firms is unlikely to be randomly distributed across jobs and workplaces. In other words, differences between jobs where the boss is female and those where the boss is male might depend, on top of the observed factors, also on job and workplace characteristics that are unobserved. Moreover, the likelihood of observing more females in some jobs, as well as more female bosses, may also depend on the lower propensity to discriminate against women, such that reverse

\footnotetext{
${ }^{8}$ Female share represents the average share of female employees in the job, where the latter is identified by occupation, firmsize, country and year.

${ }^{9}$ To measure employees' risk aversion we exploit the following questions: "Does your job require the use of protective equipment?" and "Do you always use it when it's required?". We then built a binary indicator for risk aversion that takes value 1 if the answer to both questions is "yes", while it is 0 if the job requires the use of protective equipment but the individual answered "no" to the second question. The latter question however is available only in the $5^{t} h$ wave (2010).
} 
causation is also likely to affect our estimates. While we do a good job in controlling for most factors that, in the gender discrimination literature, have been shown to be relevant in explaining inequalities across gender at the workplace, still estimates of the effect of bosswoman in equation (1) cannot be interpreted in a causal way. In this respect, to account for unobserved heterogeneity, we estimate the model saturating our baseline specification with country-time-firm size fixed effects, as well as with country specific time trends. Also, to address the potential problems associated with the existence of a selection process driving females in leadership positions, we complement our analysis estimating the selection process for a woman to become a "boss" jointly with the gender discrimination equation. In this case, our identification strategy is based on a set of instruments drawn from external information related to both institutional differences in the generosity of national parental leave systems, and labor market institutions influencing employees' career opportunities.

\section{$5 \quad$ Results}

We begin estimating equation (1) on the pooled male-female sample. Table 2 reports the estimated coefficients under different specifications. We include the bosswoman dummy variable, the female dummy and the femaleshare variable indicating the share of females in the job, while the list of other controls is reported at the bottom of Table 2. In columns 2 to 4 additional variables are added to control for work intensity, time flexibility and work environment. The estimated coefficient on the female dummy indicates that female employees always report higher gender discrimination at the workplace, as opposed to male employees.

Other controls for demographic attributes (not reported in Table 2) show that discrimination is lower for older workers and those in couple, while the share of women in the job and educational attainment are never statistically significant 10 .

The presence of a female boss is statistically significant and negatively associated with gender discrimination, and the results do not change (see the estimated coefficient of bosswoman in columns 2, 3 and 4) as we include additional controls on work organization practices, work-life balance and work environment characteristics.

In our preferred specification, reported in column 4, work organization attributes show that high work intensity (in terms of pace of work together with not-having enough time to get the job done) is positively correlated with gender discrimination, while time flexibility (in terms of working long hours and being able to take a break when needed) and a favorable work environment (work-life balance and support from colleagues) are negatively correlated with discrimination. These findings provide support for the hypothesis that female leadership is associated to lower perceived gender discrimination at work, and that the presence of a supportive work environment and a better balance between work and life further contribute to reinforce their perception.

In terms of (average) marginal effects, simply shifting from a male to a female boss - ceteris paribus - implies an overall reduction of 0.6 per cent in the likelihood

\footnotetext{
${ }^{10}$ The full set of results (column 4) is presented in the Appendix; Tables A2 and A3.
} 
of reporting gender discrimination.

Table 2 - Gender discrimination and female leadership

\begin{tabular}{|c|c|c|c|c|}
\hline & \multicolumn{4}{|c|}{ Pooled sample } \\
\hline & $(1)$ & (2) & (3) & (4) \\
\hline bosswoman & $\begin{array}{c}-0.165^{* * *} \\
(0.0536)\end{array}$ & $\begin{array}{c}-0.183^{* * *} \\
(0.0531)\end{array}$ & $\begin{array}{c}-0.187^{* * *} \\
(0.0528)\end{array}$ & $\begin{array}{c}-0.183^{* * *} \\
(0.0528)\end{array}$ \\
\hline female & $\begin{array}{c}0.701^{* * *} \\
(0.0591)\end{array}$ & $\begin{array}{c}0.713^{* * *} \\
(0.0592)\end{array}$ & $\begin{array}{c}0.746^{* * *} \\
(0.0605)\end{array}$ & $\begin{array}{c}0.753^{* * *} \\
(0.0612)\end{array}$ \\
\hline \multicolumn{5}{|l|}{ Work intensity } \\
\hline pace of work & & $\begin{array}{c}0.241 * * * \\
(0.0512)\end{array}$ & $\begin{array}{c}0.210^{* * *} \\
(0.0516)\end{array}$ & $\begin{array}{c}0.193^{* * *} \\
(0.0522)\end{array}$ \\
\hline enough time & & $\begin{array}{c}-0.290^{* * * *} \\
(0.0513)\end{array}$ & $\begin{array}{c}-0.239 * * * \\
(0.0512)\end{array}$ & $\begin{array}{c}-0.195 * * * \\
(0.0514)\end{array}$ \\
\hline \multicolumn{5}{|l|}{ Time Flexibility } \\
\hline long hours & & & $\begin{array}{c}0.245^{* * *} \\
(0.0471)\end{array}$ & $\begin{array}{c}0.193^{* * *} \\
(0.0484)\end{array}$ \\
\hline breaks at work & & & $\begin{array}{c}-0.193^{* * *} \\
(0.0437)\end{array}$ & $\begin{array}{c}-0.168^{* * *} \\
(0.0437)\end{array}$ \\
\hline \multicolumn{5}{|l|}{ Work Environment } \\
\hline colleagues support & & & & $\begin{array}{c}-0.0983 \\
(0.0599)\end{array}$ \\
\hline work-life balance & & & & $\begin{array}{c}-0.363^{* * *} \\
(0.0538)\end{array}$ \\
\hline constant & $\begin{array}{c}-2.620^{* * *} \\
(0.189)\end{array}$ & $\begin{array}{c}-2.491^{* * *} \\
(0.199)\end{array}$ & $\begin{array}{c}-2.527^{* * * *} \\
(0.210)\end{array}$ & $\begin{array}{c}-2.155^{* * *} \\
(0.222) \\
\end{array}$ \\
\hline Female share & $\checkmark$ & $\checkmark$ & $\checkmark$ & $\checkmark$ \\
\hline Demographics & $\checkmark$ & $\checkmark$ & $\checkmark$ & $\checkmark$ \\
\hline Industry and occupation & $\checkmark$ & $\checkmark$ & $\checkmark$ & $\checkmark$ \\
\hline Country and Year dummies & $\checkmark$ & $\checkmark$ & $\checkmark$ & $\checkmark$ \\
\hline pseudo- $R^{2}$ & 0.0847 & 0.1012 & 0.1111 & 0.1216 \\
\hline $\mathrm{N}$ & 63,318 & 63,318 & 63,318 & 63,318 \\
\hline
\end{tabular}

${ }^{*} \mathrm{p}<0.1,{ }^{* *} \mathrm{p}<0.05,{ }^{* * *} \mathrm{p}<0.01 ;$ robust standard errors in parentheses.

Demographics (3 age classes, 2 dummies for educational attainment, dummy for the presence of a partner); Industry and occupation (7 dummies for occupation, 9 dummies for industry, tenure, log of firm size and a public sector dummy).

These findings are consistent with both taste and statistical theories of discrimination. In the first case, female bosses are found to have no (or at least lower) taste for gender discrimination, as opposed to male bosses, which could be rationalized in terms of prejudice, cultural factors and social norms (Bertrand, 2011). In the second case, female bosses are deemed to be better at assessing the (unobserved) productivity of their female subordinates, thus improving the (gender) allocation of work, as well as the rewards, thereby reducing discrimination (Aigner and Cain, 1977).

An underlying hypothesis of the empirical specification reported in Table 2 is that, while gender discrimination is found to be higher among women, the association of having a female boss (as well as other characteristics) with gender discrimination is restricted to be the same across males and females. However, as found in the literature, the gender of the boss may be expected to play a role in shaping the relationship between discrimination, work environment and leadership. To assess this, in Table 3, we estimate our preferred specification separately for male and female employees 11 . Interestingly, the coefficient of the variable bosswoman shows

\footnotetext{
${ }^{11}$ Since there are no male employees that report gender discrimination in the "Electricity, gas and water supply" industry, as well as in Estonia, 1,057 observations are dropped from the male equation.
} 
an opposite sign across gender: female leadership, ceteris paribus, is found to be associated with lower perceived gender discrimination among female employees, while it is associated with higher discrimination among males.

This finding supports existing evidence from laboratory and field experiments showing that female bosses tend to behave differently when dealing with female coworkers, as opposed to males, as well as when employed in predominantly female jobs compared to male-dominated jobs. In the context of statistical discrimination this also confirms the hypothesis that female bosses may have a comparative advantage in assessing females' (unobserved) productivity but not that of males, such that the lower gender discrimination perceived by female employees may come at a cost of a higher discrimination reported by males. In terms of (average) marginal effects, a shift from male to female boss is associated with a reduction in the probability of reporting discrimination among females of about 1.5 per cent, whereas it shows a 0.4 per cent higher probability of discrimination among males.

Table 3 - Gender discrimination and female leadership (by gender)

\begin{tabular}{|c|c|c|c|c|c|c|}
\hline & \multicolumn{3}{|c|}{ Females } & \multicolumn{3}{|c|}{ Males } \\
\hline & (1) & (2) & (3) & (4) & (5) & (6) \\
\hline bosswoman & $\begin{array}{c}-0.241^{* * *} \\
(0.0568)\end{array}$ & $\begin{array}{c}-0.249^{* * *} \\
(0.0565)\end{array}$ & $\begin{array}{c}-0.246^{* * *} \\
(0.0564)\end{array}$ & $\begin{array}{l}0.197^{* *} \\
(0.0991)\end{array}$ & $\begin{array}{l}0.200^{* *} \\
(0.0989)\end{array}$ & $\begin{array}{l}0.207^{* *} \\
(0.0990)\end{array}$ \\
\hline \multicolumn{7}{|l|}{ Work intensity } \\
\hline pace of work & $\begin{array}{c}0.224^{* * *} \\
(0.0581)\end{array}$ & $\begin{array}{c}0.180^{* * *} \\
(0.0591)\end{array}$ & $\begin{array}{c}0.157^{* * *} \\
(0.0598)\end{array}$ & $\begin{array}{c}0.338^{* * *} \\
(0.100)\end{array}$ & $\begin{array}{c}0.328^{* * *} \\
(0.0994)\end{array}$ & $\begin{array}{c}0.319 * * * \\
(0.0996)\end{array}$ \\
\hline enough time & $\begin{array}{c}-0.285^{* * *} \\
(0.0635)\end{array}$ & $\begin{array}{c}-0.226^{* * *} \\
(0.0638)\end{array}$ & $\begin{array}{c}-0.180^{* * *} \\
(0.0652)\end{array}$ & $\begin{array}{c}-0.310^{* * *} \\
(0.0860)\end{array}$ & $\begin{array}{c}-0.279 * * * \\
(0.0833)\end{array}$ & $\begin{array}{r}-0.240^{* * *} \\
(0.0803)\end{array}$ \\
\hline \multicolumn{7}{|l|}{ Time Flexibility } \\
\hline long hours & & $\begin{array}{c}0.333^{* * *} \\
(0.0565)\end{array}$ & $\begin{array}{c}0.274^{* * *} \\
(0.0568)\end{array}$ & & $\begin{array}{c}0.0911 \\
(0.0809)\end{array}$ & $\begin{array}{c}0.0518 \\
(0.0867)\end{array}$ \\
\hline breaks at work & & $\begin{array}{c}-0.224^{* * *} \\
(0.0522)\end{array}$ & $\begin{array}{c}-0.193^{* * *} \\
(0.0523)\end{array}$ & & $\begin{array}{c}-0.106 \\
(0.0778)\end{array}$ & $\begin{array}{l}-0.0915 \\
(0.0778)\end{array}$ \\
\hline \multicolumn{7}{|l|}{ Work Environment } \\
\hline colleagues support & & & $\begin{array}{l}-0.128^{*} \\
(0.0717)\end{array}$ & & & $\begin{array}{c}-0.0260 \\
(0.120)\end{array}$ \\
\hline work-life balance & & & $\begin{array}{c}-0.412^{* * *} \\
(0.0636)\end{array}$ & & & $\begin{array}{c}-0.273^{* * *} \\
(0.0948)\end{array}$ \\
\hline constant & $\begin{array}{c}-1.527^{* * *} \\
(0.236)\end{array}$ & $\begin{array}{c}-1.559^{* * *} \\
(0.244)\end{array}$ & $\begin{array}{c}-1.119^{* * *} \\
(0.253)\end{array}$ & $\begin{array}{c}-2.999 * * * \\
(0.393)\end{array}$ & $\begin{array}{c}-2.981^{* * *} \\
(0.410)\end{array}$ & $\begin{array}{c}-2.738^{* * *} \\
(0.442)\end{array}$ \\
\hline Female share & $\checkmark$ & $\checkmark$ & $\checkmark$ & $\checkmark$ & $\checkmark$ & $\checkmark$ \\
\hline Demographics & $\checkmark$ & $\checkmark$ & $\checkmark$ & $\checkmark$ & $\checkmark$ & $\checkmark$ \\
\hline Industry and occupation & $\checkmark$ & $\checkmark$ & $\checkmark$ & $\checkmark$ & $\checkmark$ & $\checkmark$ \\
\hline Country and Year dummies & $\checkmark$ & $\checkmark$ & $\checkmark$ & $\checkmark$ & $\checkmark$ & $\checkmark$ \\
\hline pseudo- $R^{2}$ & 0.0676 & 0.0835 & 0.0965 & 0.1267 & 0.1289 & 0.1356 \\
\hline $\mathrm{N}$ & 31,637 & 31,637 & 31,637 & 30,624 & 30,624 & 30,624 \\
\hline
\end{tabular}

${ }^{*} \mathrm{p}<0.1,{ }^{* *} \mathrm{p}<0.05,{ }^{* * *} \mathrm{p}<0.01$; robust standard errors in parentheses.

Empirical specification as in Table 2, column 4.

While these effects may appear small in magnitude, it should be recalled that our indicator of gender discrimination measures a relatively "rare" event, that is an episode of gender discrimination experienced by the individual in the last 12 months. Work 
organization attributes also show interesting differences and similarities across gender. Overall high work intensity, measured by the pace of work and not-having enough time, is positively associated with gender discrimination for both males and females, suggesting that the workload in the allocation of tasks contributes to gender imbalances within firms. Conversely, time flexibility, in terms of not working long-hours and being able to take a break when needed, only affects discrimination for female employees, having no effects on males. In line with the findings of Goldin (2014) - who argues that part of the gender pay gap found in most sectors and occupations can be explained by the presence of high rewards for (long) hours worked - we find that long and rigid working time schedules contribute to perceived gender discrimination among women but not among men. In other words, since women typically put more value on time flexibility than men, working long hours imposes a larger implicit cost on women and resulting higher perceived discrimination.

Practices directed at improving employees' work-life balance are strongly and negatively associated with gender discrimination for both sexes, but with an estimated (average) marginal effect that is significantly larger for females. Other aspects of the work environment, such as getting colleagues' support, are only weakly associated with lower discrimination for females, while the relationship is not statistically significant for men.

Overall, the above results confirm a number of stylized facts traditionally found in the gender discrimination literature. First, the presence of women in leadership positions is associated to a lower overall gender discrimination, both because women are those who mainly experience discrimination within workplaces and because the estimated marginal effect of the bosswoman dummy is larger (and negative) for women as compared to men (where it is positive), suggesting that the effect on women always dominates that on men. In this respect, it could be argued that female leadership has a welfare improving effect on employees' perceived discrimination. Second, gender discrimination within firms is generally associated to unfavorable work organization practices, while it appears to be alleviated by better work-life balance arrangements, that are generally more diffused in predominantly female jobs.

While the above findings are indicative of the role of women bosses and work organization practices on gender inequalities and discriminatory behaviors, they do not shed light on the channels through which female leadership and female representation interact within firms. The next section is devoted to the investigation of the mechanisms that shape gender differences and perceived discrimination in organizations.

\section{Mechanisms}

There are several ways through which female leadership may influence gender imbalances and discrimination within firms. As discussed above, bosses are expected to generate spillovers on subordinates in terms of firms' hiring, promotion and compensation policies. Moreover, the gender composition of an organization, or the gender of the boss may shape the way these policies are implemented, as suggested 
by the "women helping women" hypothesis. Another interesting mechanism through which female leadership is expected to affect gender inequalities within firms is via the management style, the organization of work and the allocation of tasks within occupations. Hence, one reason why women tend to be concentrated in specific occupations may be related to the presence of a better gender balance, or a lower perceived penalty associated to working-time flexibility and work intensity, in jobs characterized by more family-friendly environments (Goldin, 2014). In what follows we exploit the rich set of information on job attributes and work organization practices that are available in our dataset, in order to validate the empirical relevance of the above hypotheses.

Table 4 - Gender discrimination and the "women helping women" hypothesis

\begin{tabular}{|c|c|c|c|c|c|c|}
\hline & (1) & (2) & (3) & (4) & (5) & (6) \\
\hline & $F$ & $M$ & $F$ & $M$ & $F$ & $M$ \\
\hline bosswoman & $\begin{array}{l}-0.286 \\
(0.181)\end{array}$ & $\begin{array}{l}0.435^{* *} \\
(0.205)\end{array}$ & & & & \\
\hline femaleshare & $\begin{array}{l}-0.355 \\
(0.247)\end{array}$ & $\begin{array}{c}0.707^{* * *} \\
(0.343)\end{array}$ & & & & \\
\hline bosswoman $*$ femaleshare & $\begin{array}{l}0.0746 \\
(0.305)\end{array}$ & $\begin{array}{l}-0.445 \\
(0.359)\end{array}$ & & & & \\
\hline bosswoman*mostlywomen & & & $\begin{array}{c}-0.221 * * * \\
(0.0653)\end{array}$ & $\begin{array}{c}0.182 \\
(0.126)\end{array}$ & $\begin{array}{c}-0.477 * * * * \\
(0.0967)\end{array}$ & $\begin{array}{c}0.413^{* *} \\
(0.178)\end{array}$ \\
\hline bosswoman*mostlymen/even & & & $\begin{array}{c}-0.291 * * * \\
(0.0916)\end{array}$ & $\begin{array}{c}0.242 \\
(0.152)\end{array}$ & $\begin{array}{c}-0.295^{* *} \\
(0.142)\end{array}$ & $\begin{array}{l}0.0447 \\
(0.187)\end{array}$ \\
\hline female share & & & $\begin{array}{c}-0.378 \\
(0.239)\end{array}$ & $\begin{array}{l}0.657^{*} \\
(0.342)\end{array}$ & $\begin{array}{c}0.145 \\
(0.414)\end{array}$ & $\begin{array}{l}1.181^{*} \\
(0.637)\end{array}$ \\
\hline constant & $\begin{array}{c}-1.106^{* * *} \\
(0.251)\end{array}$ & $\begin{array}{c}-2.771^{* * *} \\
(0.447)\end{array}$ & $\begin{array}{c}-1.097^{* * * *} \\
(0.251)\end{array}$ & $\begin{array}{c}-2.748^{* * * *} \\
(0.447)\end{array}$ & $\begin{array}{c}-1.334^{* * * *} \\
(0.405)\end{array}$ & $\begin{array}{c}-2.538^{* * *} \\
(0.713)\end{array}$ \\
\hline pseudo- $R^{2}$ & 0.0965 & 0.1361 & 0.0967 & 0.1356 & 0.1292 & 0.1916 \\
\hline $\mathrm{N}$ & 31,637 & 30,624 & 31,637 & 30,624 & 11,398 & 9,828 \\
\hline
\end{tabular}

${ }^{*} \mathrm{p}<0.1,{ }^{* *} \mathrm{p}<0.05,{ }^{* * *} \mathrm{p}<0.01$; robust standard errors in parentheses. Empirical specification as in Table 2, column 4.

In Table 4 we report estimates that evaluate the relevance of the "women helping women" hypothesis, that is the existence of spillover effects between a female boss and the presence of predominantly female (male) employees in the job, on perceived gender discrimination. Since the spillover effect of female leadership may differ across gender, we also run the analysis separately for male and female employees. In other words, we try to assess whether having a woman as immediate boss makes a difference when the subordinate employee occupies a predominantly male or female job.

To do this, in columns 1 and 2, we interact the bosswoman dummy with the share of females in the job, which we compute by occupation and firm size (large and small) in each country and year. Next, in columns 3 to 4, we interact the bosswoman dummy with two discrete indicators, one that takes value 1 when the share of females in the job - defined as above - is (strictly) above 50 per cent (i.e. mostlywomen), the other that takes value 1 when the share of females in the job is equal or below 50 per cent (mostlymen/even) 12. Finally, in columns 5 and 6 , we rely on a more precise definition drawn from a specific question (i.e. available only in the 2010 wave)

\footnotetext{
${ }^{12}$ Experimentation with slightly different thresholds produces similar results.
} 
asking the respondent about the predominantly female (or male) nature of similar jobs within the firm 13 .

The estimated coefficients on the interaction terms reported in columns 1 and 2 show the expected sign but are never statistically significant. Since we rely on survey data to compute the share of females in the job, measurement error and the presence of attenuation bias may drive our estimates towards zero. In columns 3 and 5, the estimated coefficients on the interaction of the bosswoman dummy both with predominantly female and male type of jobs, show the expected negative sign and are always statistically significant, indicating that female bosses are likely to be associated with lower perceived discrimination by female employees across all type of jobs. Conversely, in the male equation, a positive and statistically significant coefficient is detected on the interaction of the bosswoman dummy and female dominated jobs (column 6), suggesting that male employees perceive to be discriminated by a female boss mainly when employed in female dominated jobs (or where the share of females in the job is higher).

In the last part of this section, we investigate the role of female leadership on gender discrimination considering how work is organized within occupations. We ask whether having an immediate boss who is a woman has a pervasive effect all along the hierarchical structure - i.e. higher ranks within occupations - and not just in executive or managerial positions ${ }^{14}$. In other words, we relate the way in which work is organized within occupations, to the role that female leadership can have in mitigating the gender inequalities, or gender bias, arising from informational asymmetries or differences across gender in work-life balance needs. We expect this mitigating effect of having a woman as a boss to be stronger in those occupations where work is organized around high commitment and effort, where time schedules are rather inflexible and tasks are not easily substitutable, such that women are more likely to be disadvantaged in terms of work-life balance (Goldin, 2014). The analysis by occupation also has some additional advantages, first it contributes to mitigate the selection bias induced by the endogenous allocation of women between occupations (although not within them), second it allows an analysis of how female leadership interacts with work organization practices in explaining gender discrimination within workplaces, instead of relegating the effects to the (firms) fixed effects.

In Table 5, we report the estimates of our baseline specification for eight different occupational categories (1 digit ISCO-88 classification). Executive directors and managers are grouped in the highest rank of the occupational hierarchy; there are four different occupations for white-collar employees (Professionals, Technicians, Clerks and Service Workers), and three occupations for blue-collar workers (Craft and Trade, Plant operators and Elementary occupations). The above occupational classification is rather broad and likely to hide substantial heterogeneity, within each occupational level, across both skill levels and work tasks. Nevertheless, it tries

\footnotetext{
${ }^{13}$ The exact wording of the question is: "At your place of work are workers with the same job title as you" (Mostly women/Mostly men/More or less equal numbers of men and women).

${ }^{14}$ Given the definition of the bosswoman dummy variable, the interpretation of female leadership within each occupations is different compared to most existing studies in the literature.
} 


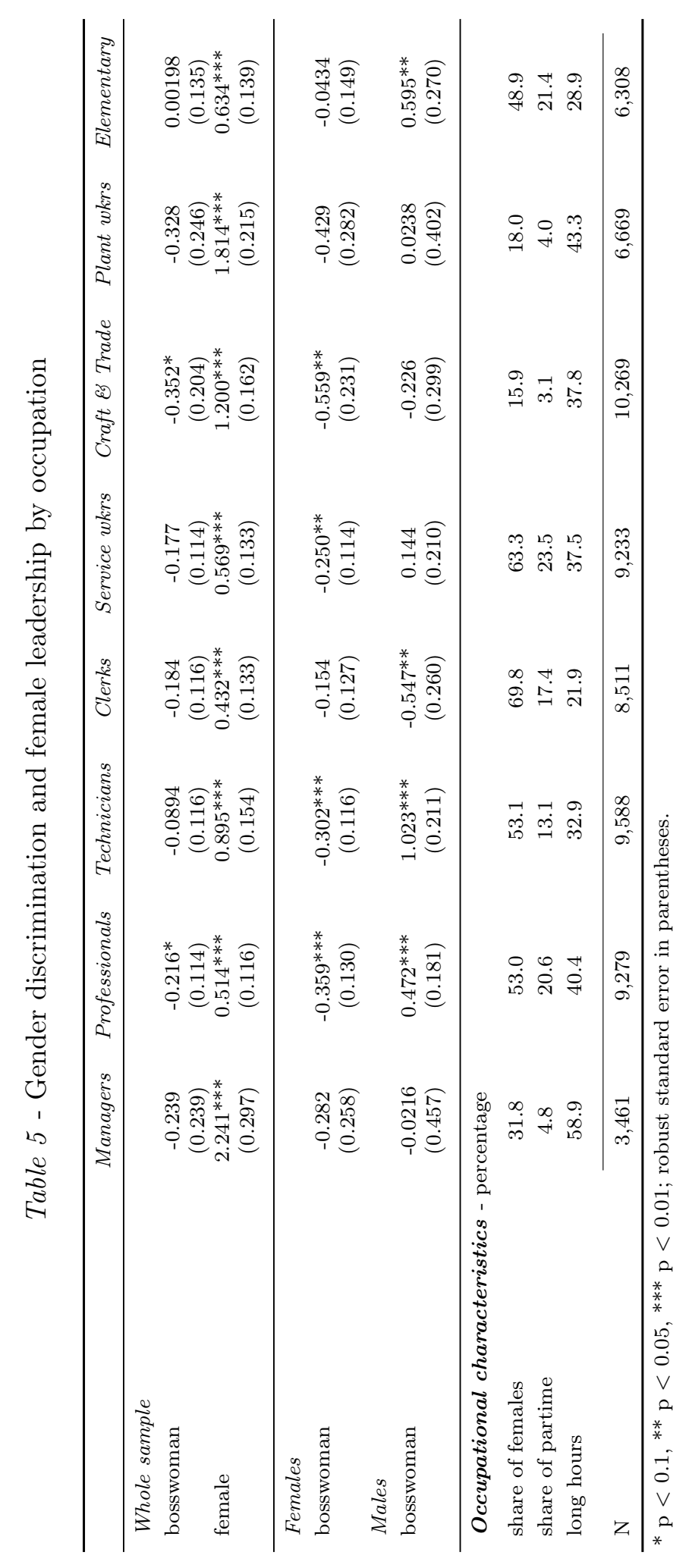


to strike a balance between the number of observations necessary to run the analysis in each occupational group and a disaggregation suitable to characterize the relationship between female leadership and work organization practices. For each occupational level, we report the coefficient estimates of our variables of interest for the whole sample and separately for males and females. We also report the averages for selected characteristics, as the share of females, share of part-time and proportion of employees working long hours.

Estimates of the female dummy, in the pooled sample, confirm that discrimination, within each occupation, is mainly perceived and reported by females. In terms of (average) marginal effects, the probability of reporting discrimination for a female employee, as opposed to a male, is highest among Executives and Managers (9\%), Craft and Trade (4.9\%) and Plant workers (8.5\%), while it is lowest among Clerks (1.8\%). Incidentally, occupations in which the probability of reporting gender discrimination is estimated to be highest are all male-dominated and have in common both a low share of part-time workers and a high share of employees working long hours (see the bottom panel in Table 5). In the low discrimination occupations, perhaps not surprisingly, the share of females is higher and only a small share of employees work long hours. In other words, this pattern seems consistent with the hypothesis that gender discrimination, or gender bias, is higher where work is organized on tight schedules and where there is little working time flexibility, while it is lower where part-time and work-life balance arrangements are more diffused. The coefficients on the bosswoman dummy show the expected negative association with gender discrimination across all occupational categories, although estimates are almost never statistically significant.

When the sample is split by gender, we get a negative and statistically significant association in the female equation and a positive, often not statistically significant, association in the male equation (with the only exception of Clerks). It is interesting to note that for Executives and Managers, we find no statistically significant effect of female leadership on gender discrimination for both sexes. Given that in managerial occupations gender discrimination is reported to be highest, this may appear surprising. One explanation is that female managers who reached the top of the occupational hierarchy are a very selected group and likely to behave "like men" toward their immediate subordinates, even showing an aversion toward women that compete for a similar position to their own (i.e. the so-called "Queen-bee syndrome").

In high-skilled white-collar occupations, such as Professional and Technicians, we find a statistically significant effect of female leadership (in terms of average partial effect we find a $2 \%$ change in the probability of gender discrimination), which is again negative in the female equation and positive for male employees. In such occupations, where high-educated women are largely represented, the demand for more familyfriendly policies is high, and female leadership can (and does) make a difference in mitigating gender bias among female employees, while it has the opposite effect on males. As we move down toward less-skilled white-collar and blue-collar occupations, the pattern is similar with a negative effect for females and virtually no-effect for males. In this respect, it is interesting to note that the only two occupations where 
the bosswoman dummy is not statistically significant in the female equation are Clerks and Elementary jobs, where the proportion of employees working long hours is lowest and part-time is relatively high.

With respect to the other work organization variables included in the analysis (not reported here), we find, for all occupational groups, that work intensity and nothaving enough time to do the job are unambiguously associated with higher gender discrimination for both male and female employees, conversely working long hours is generally positive and statistically significant only in the female equation but not in the male equation. The variables concerning the family-friendliness of the work environment are negative and significant in the female equation and generally not significant in the male equation 15 ,

While certainly some care is needed in interpreting the above results, as some unobserved attributes may drive the sorting of employees and female bosses across jobs and occupations, overall these findings provide robust evidence of a negative (positive) association between women in higher ranks (within each occupational group) and perceived discrimination by female (male) employees, a pattern that is also consistent with the way work is organized in terms of flexible working time and family-friendly practices ${ }^{16}$.

Figure 2 - Predicted discrimination and family-friendly work environment by occupation

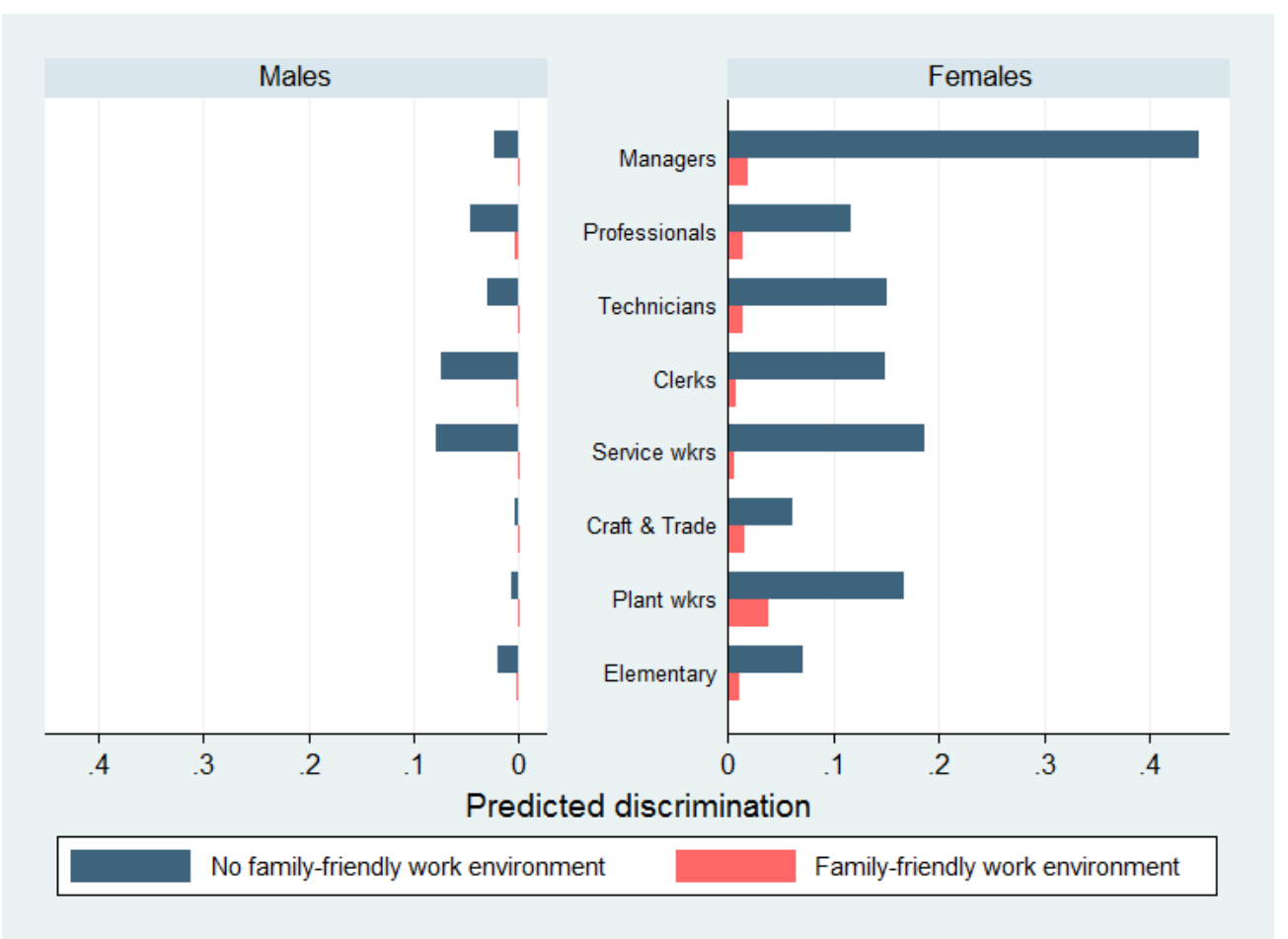

To show the relevance of the work environment for employees perceptions of gender discrimination and gender bias in the organization of work, in Figure 2 we report, for each occupation and sex, the extent of discrimination that would prevail

\footnotetext{
${ }^{15}$ The whole set of results, not reported in Table 5 , is available upon request with the authors.

${ }^{16}$ In this respect, Goldin (2014) shows that, even accounting for possible selection mechanisms, still a significant fraction of wage differentials between men and women can be explained by occupational differences in time flexibility and its associated costs.
} 
in a job with (or without) a family-friendly work environment. In practice, using our coefficient estimates by occupation, we predict gender discrimination setting job attributes - in terms of work intensity, time flexibility and work-life balance - to represent a family-friendly as opposed to a non-family-friendly work environment. Comparing two jobs with and without family-friendly attributes in the same occupational category, we find that the latter is associated with a much higher perceived gender discrimination among female employees, while it makes little or no difference for male employees. In particular, the average predicted probability of reporting gender discrimination is estimated to be highest among female managers (45\%) and in most white-collar occupations (from $13 \%$ to $19 \%$ ), where such practices are rare or less common. These findings are consistent with the evidence reported in Goldin (2014), who finds that the penalties in terms of the gender pay gap are generally larger for highly-educated workers.

\section{Robustness checks}

In order to test the robustness of our main findings, in this section we perform a number of sensitivity checks. We experiment several changes with respect to the model specification, different sub-samples of the population and clusters of countries, as well as alternative estimation methods. We report the coefficients of our main variables of interest (bosswoman and female dummies) in Table $6{ }^{17}$. All robustness checks are performed on our preferred specification (column 4 in Table 2) and using the male-female pooled sample to avoid small sample biases ${ }^{18}$

Notice that, since the estimated coefficient on the bosswoman dummy has shown opposite signs across the female and male equations - with the marginal effect for females generally dominating, in magnitude, that of males -, a negative sign would be in line with an overall mitigating effect of female leadership on gender discrimination. First, we test whether our results are robust to changes in the reference sample (rows 1 to 7 ). Since our previous results showed that working long hours and being employed in larger establishments are positively associated with the probability of reporting gender discrimination, we replicate our exercise for employees working fulltime, part-time, in large and in small firms. In general, results show that the sign and significance of the coefficients of interest are not altered by the change in the reference population.

Second, we check the sensitivity of the results to the contribution of a specific country or set of countries (rows 8 to 11). The estimates and the statistical significance we obtain re-estimating the model excluding one country at the time does not alter the main findings. We always find that female employees are more likely to report gender discrimination (estimates range from 0.66 to 0.80 ), as compared to men; and that having a woman as immediate boss has an overall negative effect on perceived discrimination which is always statistically significant (estimates range from -0.225 to -0.16$)$.

\footnotetext{
${ }^{17}$ For each model we also report the Wald- $\chi^{2}$ test for the joint significance of all predictors

${ }^{18}$ Disaggregation by gender is not feasible in the specification checks, as we test the robustness of our results across different sub-samples.
} 
Table 6 - Robustness checks

\begin{tabular}{|c|c|c|c|c|}
\hline & \multicolumn{2}{|c|}{ Estimated coefficients } & \multirow{2}{*}{$\begin{array}{l}\text { Wald- } \chi^{2} \\
\text { (p-value) }\end{array}$} & \multirow[t]{2}{*}{ Obs. } \\
\hline & Bosswoman & Female & & \\
\hline \multicolumn{5}{|l|}{ Different samples } \\
\hline 1. Fulltime & $\begin{array}{c}-0.159 * * * \\
(0.0592)\end{array}$ & $\begin{array}{c}0.789^{* * *} \\
(0.0634)\end{array}$ & $\begin{array}{l}575.04 \\
(0.000)\end{array}$ & 54,760 \\
\hline 2. Part-time & $\begin{array}{c}-0.239 * * \\
(0.104)\end{array}$ & $\begin{array}{c}0.509^{* * *} \\
(0.183)\end{array}$ & $\begin{array}{l}269.03 \\
(0.000)\end{array}$ & 7,839 \\
\hline 3. Fulltime \& high_edu & $\begin{array}{c}-0.246^{* * *} \\
(0.0795)\end{array}$ & $\begin{array}{c}0.849^{* * *} \\
(0.0947)\end{array}$ & $\begin{array}{l}361.62 \\
(0.000)\end{array}$ & 20,107 \\
\hline 4. Large firm $(>=100)$ & $\begin{array}{c}-0.334^{* * *} \\
(0.0905)\end{array}$ & $\begin{array}{c}0.793^{* * *} \\
(0.106)\end{array}$ & $\begin{array}{l}323.29 \\
(0.000)\end{array}$ & 18,704 \\
\hline 5. Small firm $(<100)$ & $\begin{array}{l}-0.114^{*} \\
(0.0635)\end{array}$ & $\begin{array}{c}0.762^{* * *} \\
(0.0714)\end{array}$ & $\begin{array}{l}480.80 \\
(0.000)\end{array}$ & 44,614 \\
\hline 6. Public sector & $\begin{array}{c}-0.267^{* * *} \\
(0.0859)\end{array}$ & $\begin{array}{c}0.705^{* * *} \\
(0.101)\end{array}$ & $\begin{array}{l}352.61 \\
(0.000)\end{array}$ & 21,310 \\
\hline 7. Private sector & $\begin{array}{l}-0.123^{*} \\
(0.0639)\end{array}$ & $\begin{array}{c}0.798^{* * *} \\
(0.0758)\end{array}$ & $\begin{array}{l}487.82 \\
(0.000)\end{array}$ & 42,008 \\
\hline \multicolumn{5}{|l|}{ Different samples by country } \\
\hline 8. Drop countries:range $[\min ; \max ]^{\mathrm{a}}$ & {$\left[-0.225^{\left.* * * ;-0.157^{* * *}\right]}\right.$} & {$\left[0.657^{* * *} ; 0.803^{* * *}\right]$} & & \\
\hline 9. Drop outliers ${ }^{\mathrm{b}}$ & $\begin{array}{c}-0.181^{* * *} \\
(0.053)\end{array}$ & $\begin{array}{c}0.754^{* * *} \\
(0.062)\end{array}$ & $\begin{array}{l}573.44 \\
(0.000)\end{array}$ & 59,629 \\
\hline 10. Drop outliers ${ }^{c}$ & $\begin{array}{c}-0.221^{* * *} \\
(0.053)\end{array}$ & $\begin{array}{c}0.796^{* * *} \\
(0.065)\end{array}$ & $\begin{array}{l}555.01 \\
(0.000)\end{array}$ & 59,960 \\
\hline 11.Only EU28 & $\begin{array}{c}-0.224^{* * *} \\
(0.053)\end{array}$ & $\begin{array}{c}0.798^{* * *} \\
(0.064)\end{array}$ & $\begin{array}{l}572.52 \\
(0.000)\end{array}$ & 60,449 \\
\hline \multicolumn{5}{|l|}{ Different specifications } \\
\hline 12. control for income & $\begin{array}{c}-0.176^{* * *} \\
(0.0647)\end{array}$ & $\begin{array}{c}0.677^{* * *} \\
(0.0731)\end{array}$ & $\begin{array}{l}426.26 \\
(0.000)\end{array}$ & 44,279 \\
\hline 13. control for satisfaction & $\begin{array}{c}-0.185^{* * *} \\
(0.0537)\end{array}$ & $\begin{array}{c}0.761^{* * *} \\
(0.0061)\end{array}$ & $\begin{array}{l}658.99 \\
(0.000)\end{array}$ & 62,970 \\
\hline 14.control for social preferences & $\begin{array}{c}-0.167^{* *} \\
(0.0645)\end{array}$ & $\begin{array}{c}0.737^{* * *} \\
(0.0710)\end{array}$ & $\begin{array}{l}537.36 \\
(0.000)\end{array}$ & 45,624 \\
\hline 15.control for psychosocial environment & $\begin{array}{c}-0.218^{* * *} \\
(0.0689)\end{array}$ & $\begin{array}{l}0.676^{* * *} \\
(0.0733)\end{array}$ & $\begin{array}{l}511.87 \\
(0.000)\end{array}$ & 40,093 \\
\hline 16. control for risk aversion & $\begin{array}{l}-0.361^{* *} \\
(0.1404)\end{array}$ & $\begin{array}{l}0.767^{* * *} \\
(0.1491)\end{array}$ & $\begin{array}{l}461.58 \\
(0.000)\end{array}$ & 9,225 \\
\hline \multicolumn{5}{|l|}{ Different estimation methods } \\
\hline 17. Complementary log-log model & $\begin{array}{c}-0.412^{* * *} \\
(0.1289)\end{array}$ & $\begin{array}{c}1.866^{* * *} \\
(0.1657)\end{array}$ & $\begin{array}{l}683.04 \\
(0.000)\end{array}$ & 63,318 \\
\hline 18. Penalized likelihood model & $\begin{array}{c}-0.439^{* * *} \\
(0.0741)\end{array}$ & $\begin{array}{l}1.706^{* * *} \\
(0.0880)\end{array}$ & $\begin{array}{c}1078.89 \\
(0.000)\end{array}$ & 63,318 \\
\hline 19. Clustered std errors (country*year) & $\begin{array}{c}-0.183^{* * *} \\
(0.0614)\end{array}$ & $\begin{array}{c}0.753^{* * *} \\
(0.0752)\end{array}$ & $\begin{array}{c}10427.40 \\
(0.000)\end{array}$ & 63,318 \\
\hline
\end{tabular}

${ }^{*} \mathrm{p}<0.1,{ }^{* *} \mathrm{p}<0.05,{ }^{* * *} \mathrm{p}<0.01$; robust standard errors in parentheses (columns 2 and 3 ).

a The range of estimates is obtained excluding one country at a time from our preferred specification.

b,c Countries characterized by high bosswoman/low discrimination, i.e. Estonia, Latvia and Lithuania; and by low bosswoman/high discrimination, i.e. Turkey and Greece.

We also check whether some countries, that could be regarded as outliers in terms of either average reported discrimination or share of women in leadership position, may influence the results. In particular, Baltic countries (Estonia, Lithuania and Latvia) appear to be characterized by a higher than average share of women in 
leadership positions and by lower levels of perceived gender discrimination (even after controlling for the gender composition of the sample). Conversely, Turkey and Greece are at the other extreme, reporting high gender discrimination and a low share of female bosses. In row 11, we restrict the sample to the EU28 member countries, thus excluding Norway and Turkey which may have different institutions and cultural attitudes across gender. In all the above experimentations, we find no evidence that our main findings were affected or altered in any significant way.

Third, we check whether results are robust to the inclusion of additional controls that may be relevant in affecting gender discrimination at the workplace (rows 12 and 13). In particular, we augment the baseline specification including additional control variables for low income level (household income below the median) and low satisfaction with working conditions.

Since evidence from experimental and field studies has shown the importance of behavioral characteristics of men and women on discrimination and other laborrelated outcomes (Bertrand, 2011; Dollar et al., 2001; Niederle and Vesterlund, 2007), we also include in our estimated model (rows 14 to 16) information on preferences for social activities outside work, psycho-social work environment (i.e. perceived job security and social relationships at the workplace) and attitudes toward risk (Dohmen et al. 2011) ${ }^{19}$, In general, results are not altered by the inclusion of all the above control variables.

We also investigate the sensitivity of our estimates to the limited incidence of non-zero outcomes in our dependent variable using alternative estimation methods that are robust to distributions with a large number of zeros, such as complementary $\log$-log models ("zero-inflated" model) and penalized likelihood techniques ${ }^{20}$. Further, given the cross-country time-series dimension of our dataset, to account for possible country and time specific heteroskedasticity we also estimated our preferred specification using standard errors clustered at the country and year level. When we correct for the "rare" nature of our outcome (rows 17 and 18) or for the presence of heteroskedasticity (row 19) estimates of our variables of interest remain strongly significant and bear the expected sign.

Since our measure of discrimination may be sensitive to individual judgment and reporting bias, we test whether female employees systematically under-report gender discrimination when in a job with a female boss (see Table A4 in Appendix). If this is the case, we should expect women to report lower or no discrimination also in other domains of discrimination for which we have information, such as age, race or nationality. We experimented alternative measures of discrimination reported by employees, and found no evidence of reporting bias. In a similar exercise, we use measures of perceived health or work hazard\$ ${ }^{21}$, and also found no evidence of

\footnotetext{
${ }^{19}$ Detailed information on variables' specification can be found in the Appendix.

${ }^{20}$ Recent literature in political and social sciences has raised the issue of explaining and predicting rare events (i.e. binary dependent variables with fewer ones than zeroes) with binary choice models. Besides the bias due to small samples, recent studies (King and Zeng, 2001) have argued that in rare events data the biases in probabilities can be meaningful even with big sample sizes and that these biases result in an underestimation of event probabilities. To address these concerns we experimented both complementary log-log and penalized likelihood methods.

${ }^{21}$ We selected two questions available in each wave of the EWCS: "Do you think your health or safety is at risk because of your work?" and "does your work effect your health?".
} 
reporting bias.

Finally, we investigate the hypothesis that gender discrimination and female leadership may differ across clusters of countries (see Table A5 in the Appendix). In particular, since estimation by single country is unfeasible due to the small sample sizes, we group countries in clusters, according to some ad hoc common cultural or institutional attributes.

Overall, we do not find evidence of significant differences across country-clusters in the way female leadership is associated to gender inequalities within firms. In all clusters women (compared to men) are more likely to report gender discrimination at the workplace, and female leadership is negatively associated with gender discrimination (or not statistically significant) 23 . The association of bosswoman with overall gender discrimination in terms of (average) marginal effect shows a stronger relationship in Baltic and Eastern European (Northern) countries (around -1\%), while the effect is milder for Mediterranean countries and not statistically significant for Anglosaxon and Eastern European (Southern) countries. Whilst particular care should be used in interpreting the differences across clusters of countries - as due to small sample sizes point estimates are less precise and in some case not statistically significant -, still results are consistent with female leadership being stronger where the cultural environment is more favorable to women, and where women are more present in higher ranks of the occupational hierarchy ${ }^{24}$.

\subsection{Earnings and Career Advancement}

The measure of direct gender discrimination, or gender bias, used in this study is not standard in the literature, where variables such as pay or promotions have been used instead. To compare our main findings with existing studies, we replicate our analysis using more traditional variables. In particular, we estimate different specifications of equation (1) - on the male-female pooled sample - where the association of female leadership with gender discrimination is assessed with respect to earnings and career advancements. In order to see whether having a female boss, as opposed to a male one, is associated to a lower wage penalty or better prospects for career advancement for women (compared to men), we interact the bosswoman dummy with the female dummy. In Table 7, we also investigate the heterogeneity of the female leadership

\footnotetext{
${ }^{22}$ Country-clusters are generally classified according to welfare regimes and labor market institutions (see (Muffels and Luijkx , 2005)). In practice, we have used the following classification: Nordic (DK, SE, FI), Continental (AT, BE, DE, LU, NL, FR), Mediterranean (GR, IT, SP, PO), Anglosaxon (IRL, UK), Baltic (EE, LT, LV), Eastern/North (BG, CZ, HU, PL, SLV, SLK, RO) and Eastern/South (CY, MT, HR).

${ }^{23}$ In terms of (average) marginal effect, the probability of female employees to perceive discrimination (compared to male employees) is found to be higher in Anglosaxons (around 4\%), Nordic and Continental countries (around 3.2\%); while it is significantly lower in South-Eastern European countries (below $2 \%$ ).

${ }^{24}$ In Baltic countries where both the female employment to population ratio, and the share of females in managerial and supervisory positions are high, we find a much stronger association between female leadership and gender discrimination as compared to other country-clusters. Conversely, in Mediterranean and Eastern European (Southern) countries that are characterized by a lower share of women in leadership positions, the estimated marginal effect of female leadership on gender discrimination is significantly smaller.
} 
dummy for female dominated jobs, as compared to other jobs.

Table 7 - Female leadership, career advancements and earnings

(2010)

\begin{tabular}{lccccc}
\hline & \multicolumn{2}{c}{ Earnings } & \multicolumn{2}{c}{ Career advancements } \\
\cline { 2 - 3 } bosswoman & $(1)$ & $(2)$ & & $(3)$ & $(4)$ \\
\cline { 2 - 3 } \cline { 5 - 6 } female & $-0.0818^{* * *}$ & $-0.0827^{* * *}$ & & $-0.186^{* *}$ & $-0.212^{* * *}$ \\
bosswoman*female & $(0.0225)$ & $(0.0232)$ & & $(0.0733)$ & $(0.0766)$ \\
& $-0.205^{* * *}$ & $-0.205^{* * *}$ & & $-0.144^{* * *}$ & $-0.126^{* * *}$ \\
mostlywomen & $(0.0144)$ & $(0.0151)$ & & $(0.0439)$ & $(0.0454)$ \\
& $0.0531^{* *}$ & $0.0511^{*}$ & & $0.279^{* * *}$ & $0.226^{* *}$ \\
bosswoman*mostlywomen & $(0.0264)$ & $(0.0300)$ & & $(0.0839)$ & $(0.0900)$ \\
& $-0.111^{* * *}$ & $-0.113^{* * *}$ & & $-0.281^{* * *}$ & $-0.327^{* * *}$ \\
& $(0.0143)$ & $(0.0174)$ & & $(0.0424)$ & $(0.0534)$ \\
& & 0.00422 & & 0.121 \\
& & $(0.0283)$ & & $(0.0841)$ \\
\hline
\end{tabular}

${ }^{*} \mathrm{p}<0.1,{ }^{* *} \mathrm{p}<0.05,{ }^{* * *} \mathrm{p}<0.01 ;$ robust standard errors in parentheses. Empirical specification as in Table 2, column 4.

Estimates for the most recent wave (2010).

The main findings confirm the pay and career gender gap usually reported in the literature. Female employees, on average, earn less than men $(-20.5 \%)$, receive a lower pay if employed in a female-dominated job $(-11.0 \%)$, and are more likely to be in a leadership position in jobs where pay is, on average, lower $(-8.2 \%)$. Similar results are found when considering career opportunities, namely: female employees, on average, exhibit a lower probability of being promoted, are less likely to be promoted if there are many women around, and they reach a leadership position in jobs where, on average, the likelihood of career advancement is lower, as compared to jobs where males are higher up in the occupational hierarchy.

However, in line with our main findings, the coefficients on the interaction terms between the bosswoman dummy and the female dummy are positive and statistically significant, suggesting a mitigating role for the pay gap and an enhanced probability of career advancement when the immediate boss is a woman. Conversely, we do not find any difference in the above results if the job has predominantly female or male employees.

Overall, we find support for the hypothesis that females in executive and supervisory positions are able to reduce gender imbalances of other (female) employees in subordinate layers of the occupational hierarchy, reducing the gender gap in both pay and career opportunities.

\section{Selectivity}

The overall pattern emerging from the empirical analysis discussed in previous sections indicates the existence of a negative association between female leadership and overall gender discrimination. This effect is found to differ between female and male employees: typically strongly negative (statistically significant) for females and positive (or not statistically significant) for males, particularly in female-dominated jobs. 
Moreover, the family-friendliness of the work environment, in terms of time flexibility and work-life balance practices, is found to play a relevant role in further reducing gender discrimination.

However, since work organization practices are chosen by firms, and women are likely to sort themselves in jobs where the work environment is more family-friendly and career advancements more probable, it is difficult to discern whether the estimated effects of female leadership on gender discrimination are causal or capture simple correlations. As already discussed, the estimated effect of female leadership could reflect the fact that in firms with more family-friendly work environment (mainly demanded by women), women are more likely to be promoted in managerial and supervisory positions and gender inequalities are expected to be lower. While controlling for a large set of workplace characteristics and work organization practices, or estimating the relationship within occupational categories, should reduce the likelihood of a spurious correlation, we cannot exclude that unobserved job and workplace characteristics (i.e. unobserved heterogeneity) or the lower propensity to discriminate against women (i.e. reverse causality) affect our estimates. In all the circumstances described above, the endogenous selection process - i.e. matching family-friendly job attributes and the presence of women in managerial and supervisory positions with lower gender discrimination - is likely to provide biased estimates of the true effect of female bosses on gender discrimination.

In this section, to address the above problems, we complement our empirical strategy in two different ways. First, to account for unobserved heterogeneity, we start by saturating the baseline specification with a large set of fixed-effects obtained interacting country, industry and firm-size dummies (for a total of 660 dummies). Next, we include country-specific time trends to control for time-varying unobservables that change over time, such as changes in social norms or cultural attitudes toward gender discrimination or women in leadership positions. Second, we specify a selection equation for the probability of having a woman as boss and estimate it jointly with the probability of reporting discrimination. In practice we estimate a bivariate probit model allowing for the correlation in the error terms of the two equations. Our identification strategy exploits information on the variation, across countries and over time, in the Generosity of national Parental Leave systems (GPL), and in the stringency of Employment Protection Legislation (EPL). In particular, we instrument the probability of having a woman as immediate boss with an index of GPL that increases with the number of weeks available for maternity, parental and childcare leave (and the associated cash benefits), as well as with an EPL index which increases with the stringency of the regulation for regular and temporary employment contract:25.

The rationale behind the choice of these instruments is the following. The generosity of the welfare system with respect to parental leave, by increasing the attachment of females to their job also increases their probability of being promoted to higher ranks of the occupational hierarchy (Bøler et al., 2014). Similarly, the

\footnotetext{
${ }^{25}$ Detailed information on how we constructed of our instruments are provided in the Appendix.
} 
stringency of employment protection regulations, by protecting insiders from competition, is likely to favor employment and career progression of employees with higher seniority. Hence, in labor market segments where women are sufficiently represented, stricter EPL can foster career progression and result in a larger share of females in leadership positions. Moreover, since there are obvious complementarities between the above policies - i.e. high employment protection and high generosity mutually reinforcing the likelihood of career advancement for women - we also include an interaction term between the two indices.

Notice, however, that since the information on the GPL and EPL indices is available only for a subset of the countries in our dataset (namely EU15 and Norway), estimates of the bivariate probit model are based on this restricted sample. For comparison purposes, we also re-estimated our baseline probit model on the same restricted sample (column 3 in Table 8).

Table 8 - Gender discrimination and female leadership (heterogeneity and selection)

\begin{tabular}{|c|c|c|c|c|}
\hline & \multicolumn{2}{|c|}{ Heterogeneity } & \multicolumn{2}{|c|}{ Selection } \\
\hline & (1) & $(2)$ & $(3)$ & $(4)$ \\
\hline bosswoman & $\begin{array}{c}-0.171^{* * *} \\
(0.0528)\end{array}$ & $\begin{array}{c}-0.1858^{* * *} \\
(0.0528)\end{array}$ & $\begin{array}{c}-0.199^{* * *} \\
(0.0567)\end{array}$ & $\begin{array}{r}-0.720^{* * *} \\
(0.0992)\end{array}$ \\
\hline female & $\begin{array}{l}0.758^{* * *} \\
(0.0609)\end{array}$ & $\begin{array}{l}0.758^{* * *} \\
(0.0610)\end{array}$ & $\begin{array}{c}0.811^{* * *} \\
(0.0696)\end{array}$ & $\begin{array}{l}0.923^{* * *} \\
(0.0678)\end{array}$ \\
\hline $\begin{array}{l}\text { FE (country*industry*firmsize) } \\
\text { Country trends }\end{array}$ & $\checkmark$ & $\checkmark$ & & \\
\hline \multicolumn{5}{|l|}{ Selection Equation } \\
\hline GPL & & & & $\begin{array}{l}0.276^{* * *} \\
(0.1003)\end{array}$ \\
\hline EPL & & & & $\begin{array}{c}0.128^{*} \\
(0.0712)\end{array}$ \\
\hline $\mathrm{GPL} * \mathrm{EPL}$ & & & & $\begin{array}{c}-0.0803^{* *} \\
(0.0328)\end{array}$ \\
\hline Wald Test of rho $=0, \chi^{2}$ & & & & $27.49(\mathrm{p}=0.0000)$ \\
\hline Overidentification test statistic, $\chi^{2}$ & & & & $5.10(\mathrm{p}=0.1644)$ \\
\hline $\mathrm{N}$ & 53,409 & 63,318 & 44,475 & 44,475 \\
\hline
\end{tabular}

As in the robustness checks section, to avoid a loss of precision in our point estimates due to small sample size, we implement the above estimations only on the male-female pooled sample.

The main set of results are reported in upper panel of Table 8, while in the lower panel we report estimates of the selection equation, as well as some statistics for the validity of the instrument: 26

\footnotetext{
${ }^{26}$ The set of instruments allows for an over-identification test for the validity of the exclusion restrictions.
} 
In columns 1 and 2, we report the coefficients of our variables of interest estimated adding respectively a large set of fixed effects and country specific trends to the baseline specification. Results show that both the negative sign, the magnitude of coefficients as well as the statistical significance of the bosswoman dummy are not altered when an alternative specification is used. This suggests that timeinvariant unobserved characteristics by country, industry and firm size, or, alternatively, country-specific unobserved trends are not driving our results.

Results for the bivariate probit model are reported in column 4. Notice that the Wald test for the correlation of the error terms across the two equations strongly rejects the hypothesis of exogeneity, implying that gender discrimination and female leadership are not likely to be independent. Also, standard diagnostic tests indicate that our instruments are not weak ${ }^{27}$ and that exclusion restrictions for the validity of the instruments hold 28 ,

Hence, when we model the potential endogeneity of the bosswoman dummy, we find a larger and statistically significant negative effect of female leadership on perceived gender discrimination, suggesting that our previous estimates might have been bias downward. We interpret this evidence as providing support for a causal interpretation of the effect of female leadership on gender discrimination within firms.

\section{Conclusions}

This study presents evidence that women in leadership positions can contribute to reduce gender discrimination and perceptions of gender bias within firms. We show that female leadership is associated with an overall lower probability for employees to report being discriminated on the basis of their sex. However, this effect is shown to differ between female and male employees: lower discrimination among females and higher discrimination for males, with the former effect always dominating in magnitude. When we investigate the mechanisms underlying gender differences, we find evidence of a "women helping women" effect, suggesting that female leadership generates positive spillovers reducing discrimination, particularly where women are over-represented. We also find that the way work is organized, in terms of flexible working time and family-friendly practices, matters for gender discrimination all along the occupational hierarchy, but in particularly among women in high-skilled occupations. We find support for the above findings even when we consider more traditional variables, such as pay and career advancement. Finally, when we explicitly model the potential endogeneity of female leadership, arising from the non-random distribution of females in managerial and supervisory positions in the occupational hierarchy, we find support for a causal interpretation of our main findings. The evidence reported in this study is consistent with most of the existing literature on gender discrimination which predicts that women in leadership positions have less

\footnotetext{
${ }^{27} \mathrm{~A}$ simple $\chi^{2}$-test for the joint significance of the instruments in the selection equation confirms the relevance of the instruments.

${ }^{28}$ Overidentification test statistic in bivariate probit models is the $\chi^{2}$ statistic for the joint significance of the instruments in the structural equation for discrimination. The null hypothesis is that instruments are not jointly significant regressors in such equation.
} 
discriminatory tastes, better information to assess the productivity of other women and are less likely to introduce gender imbalances in the organization of work. In this respect, we also show that women who are in supervisory or managerial positions are an important complement to firms' practices that are more friendly to employees with family obligations (mostly women), resulting in a lower gender discrimination. We find no evidence, however, that any of the above effects hold among women at the very top of the company's occupational hierarchy (i.e. CEO or executive managers), which seems to suggest that women who are selected for those positions through highly competitive rank-ordered tournaments do not behave differently from men in similar positions. The implications of the above findings for gender discrimination at work are numerous. First, promoting a higher presence of women in leadership positions, all along the occupational structure, is an effective way of reducing gender bias and discrimination toward women in workplaces. This has a direct (causal) effect, as well as an indirect (spill-over) effect on female subordinates in predominantly female jobs. While there is evidence of an adverse effect on male employees in predominantly female jobs, it is difficult to say whether this is the result of reversal of (taste or statistical) discrimination against women, or a genuine behavioral effect of women discrimination toward men. Second, our results show that when there is a gender bias in the way work is organized (long working hours, rigid working-time schedules and low work-life balance) women are more likely to be penalized, as compared to men. Thus, promoting family-friendly work practices such as part-time work, flexible working time and parental leave arrangements is another effective way to better balance work and life across gender, particularly for women (and men) with caring responsibilities. Whether this should be done through company's welfare provided schemes, through public subsidies for part-time work and child care facilities, or both is yet to be assessed. Conversely, any company or public policy that disproportionately rewards long and inflexible working time schedules, either through company bonuses or tax-breaks on overtime work, as well as career concerns that are centered on high work intensity and rank-ordered tournaments are most likely to reduce equality of opportunities for women in organizations. While affirmative action and mandatory quotas for women in executive boards may reverse this pattern, our results suggest that female leadership can have a welfare improving effect on gender discrimination all along the occupational hierarchy.

\section{References}

Ahern, K. R. and Dittmar, A. K. (2012), 'The changing of the boards: The impact on firm valuation of mandated female board representation', Quarterly Journal of Economics 127(1), 137-197.

Aigner, D. J. and Cain, G. G. (1977), 'Statistical theories of discrimination in labor markets', Industrial and Labor Relations Review 30(2), 175-187.

Albrecht, J., Bjorklund, A. and Vroman, S. (2003), 'Is there a glass ceiling in Sweden?', Journal of Labor Economics 21(1), 145-177.

Artz, B., Goodall, A. H. and Oswald, A. J. (2014), 'Boss competence and worker well-being', IZA Discussion Paper (DP No. 8559). 
Bagues, M., Sylos-Labini, M. and Zinovyeva, N. (2014), 'Do gender quotas pass the test? Evidence from academic evaluations in italy', Scuola Superiore Sant'Anna, LEM Working Paper Series 14.

Barbulescu, R. and Bidwell, M. (2013), 'Do women choose different jobs from men? Mechanisms of application segregation in the market for managerial workers', Organization Science 24(3), 737756.

Becker, G. S. (1957), The economics of discrimination, University of Chicago press.

Bednar, S. and Gicheva, D. (2014), 'Are Female Supervisors More Female-Friendly?', American Economic Review 104(5), 370-375.

Bell, L. A. (2005), 'Women-led firms and the gender gap in top executive jobs', IZA Discussion Paper (DP No.1689).

Bertrand, M. (2011), 'New perspectives on gender', Handbook of labor economics 4, 1543-1590.

Bertrand, M., Black, S. E., Jensen, S. and Lleras-Muney, A. (2014), 'Breaking the glass ceiling? The effect of board quotas on female labor market outcomes in norway', NBER Working Paper (WP No.20256).

Bertrand, M. and Schoar, A. (2003), 'Managing with style: The effect of managers on firm policies', The Quarterly Journal of Economics 118(4), 1169-1208.

Bloom, N., Kretschmer, T. and Van Reenan, J. (2009), 'Work-life balance, management practices and productivity', International differences in the business practices and productivity of firms pp. $15-54$.

Bøler, E. A., Javorcik, B. and Ulltveit-Moe, K. H. (2014), 'Globalization: A Woman's Best Friend? Exporters and the Gender Wage Gap', CEPR Discussion Paper .

Booth, A. and Leigh, A. (2010), 'Do employers discriminate by gender? A field experiment in female-dominated occupations', Economics Letters 107(2), 236-238.

Cardoso, A. R. and Winter-Ebmer, R. (2007), 'Female-Led Firms and Gender Wage Policies', Industrial and Labor Relations Review 64(1), 143-163.

Croson, R. and Gneezy, U. (2009), 'Gender differences in preferences', Journal of Economic literature 47(2), 448-474.

Datta Gupta, N. and Eriksson, T. (2012), 'HRM Practices and the Within-Firm Gender Wage Gap', British Journal of Industrial Relations 50(3), 554-580.

Dohmen, T., Falk, A., Huffman, D., Sunde, U., Schupp, J. and Wagner, G. G. (2011), 'Individual risk attitudes: Measurement, determinants, and behavioral consequences', Journal of the European Economic Association 9(3), 522-550.

Dollar, D., Fisman, R. and Gatti, R. (2001), 'Are women really the "fairer" sex? Corruption and women in government', Journal of Economic Behavior \& Organization 46(4), 423-429.

Eurofound (2010), 'Fifth European Working Conditions Survey - Weighting Report'.

Eurofound (2012), 'Fifth European Working Conditions Survey - Overview Report'.

Flabbi, L., Macis, M., Moro, A. and Schivardi, F. (2014), 'Do Female Executives Make a Difference? The Impact of Female Leadership on Gender Gaps and Firm Performance', CEPR Discussion Paper (No.10228).

Fortin, N. M. (2008), 'The gender wage gap among young adults in the united states the importance of money versus people', Journal of Human Resources 43(4), 884-918. 
Gagliarducci, S. and Paserman, D. (2015), 'The Effect of Female Leadership on Establishment and Employee Outcomes: Evidence from Linked Employer-Employee Data', Research in Labor Economics 41, 341-372.

Gauthier, A. H. (2002), 'Family policies in industrialized countries: is there convergence?', Population $\mathbf{5 7}(3), 447-474$.

Goldin, C. (2006), 'The quiet revolution that transformed women's employment, education, and family', American Economic Review 96(2), 1-21.

Goldin, C. (2014), 'A grand gender convergence: Its last chapter', American Economic Review 104(4), 1091-1119.

Goldin, C. and Katz, L. F. (2012), 'The most egalitarian of all professions: Pharmacy and the evolution of a family-friendly occupation', NBER Working Paper (WP No.18410).

IMF (2013), 'Women, Work, and the Economy: Macroeconomic Gains from Gender Equity'.

Kato, T. and Kodama, N. (2015), 'Work-Life Balance Practices, Performance-Related Pay, and Gender Equality in the Workplace: Evidence from Japan', IZA Discussion Paper (DP No.9379).

King, G. and Zeng, L. (2001), 'Logistic regression in rare events data', Political analysis 9(2), 137163.

Kunze, A. and Miller, A. R. (2014), 'Women Helping Women? Evidence from Private Sector Data on Workplace Hierarchies', NBER Working Paper (WP No. 20761).

Lazear, E. P., Shaw, K. L. and Stanton, C. T. (2012), 'The value of bosses', NBER Working Paper (WP No.18317).

Matsa, D. A. and Miller, A. R. (2013), 'A female style in corporate leadership? Evidence from quotas', American Economic Journal: Applied Economics 5(3), 136-169.

Muffels, R. and Luijkx, R. (2005), 'Job mobility and employment patterns across European welfare states. Is there a "trade-off" or a "double bind" between flexibility and security?', Institute for Labour Studies, Amsterdam 25(05), 2010.

Neumark, D. and Gardecki, R. (1998), 'Women helping women? Role-model and mentoring effects on female Ph. D. student in economics', Journal of Human Resources, 33(1), 220-246.

Niederle, M. (2014), 'Gender', NBER Working Paper (WP No.20788).

Niederle, M. and Vesterlund, L. (2007), 'Do women shy away from competition? Do men compete too much?', Quarterly Journal of Economics 122(3), 1067-1101.

OECD (2007), 'Babies and bosses: reconciling work and family life: A synthesis of findings for OECD countries'.

Olivetti, C. and Petrongolo, B. (2016), 'The evolution of gender gaps in industrialized countries', NBER Working Paper (WP No.21887).

Weichselbaumer, D. and Winter-Ebmer, R. (2007), 'The effects of competition and equal treatment laws on gender wage differentials', Economic Policy 22(50), 236-287. 


\section{Appendix}

\section{Generosity of parental leave systems}

Information on the generosity of parental leave systems in European Countries are gathered from the dataset used in Gauthier (2002), whose sources are OECD and ILO statistics. Our index of generosity is constructed as a summary scale of 6 items (normalized to $[0,1]$ ): total number of paid weeks of maternal leave (including weeks before and after childbirth), total number of weeks of childcare leave, total number of weeks of parental leave, cash benefits received during maternity leave (as a percentage of female wages), cash benefits received during parental leave and cash benefits received during childcare leave.

\section{Employment Protection Legislation}

EPL indexes refer to OECD summary indicators of Employment Protection Legislation, measuring the procedures and costs involved in dismissing individuals (www.oecd.org/employment/EPL).

In particular, we used both the index of employment protection for regular workers, including additional provisions for collective dismissals, and the one for temporary workers, which measures the stringency of the regulation on the use of fixed-term and temporary work agency contracts. 
Table A1 - Description and means of the variables used

\begin{tabular}{|c|c|c|c|c|}
\hline \multirow[t]{2}{*}{ Variable } & \multirow[t]{2}{*}{ Description } & \multicolumn{3}{|c|}{ Mean } \\
\hline & & All & Females & Males \\
\hline discrimination_sex & $\begin{array}{l}\text { dummy }=1 \text { if respondent subjected to } \\
\text { discrimination linked to sex }\end{array}$ & 0.017 & 0.03 & 0.006 \\
\hline bosswoman & $\begin{array}{l}\text { dummy }=1 \text { if respondent's boss } \\
\text { is a woman }\end{array}$ & 0.244 & 0.43 & 0.096 \\
\hline \multicolumn{5}{|l|}{ Demographics } \\
\hline female & dummy $=1$ if female & 0.443 & & \\
\hline Age Groups: & dummies $=1$ if in age group & & & \\
\hline $15-24$ & & 0.112 & 0.115 & 0.109 \\
\hline $25-35$ & & 0.297 & 0.29 & 0.303 \\
\hline $36-55$ & & 0.512 & 0.521 & 0.505 \\
\hline $56+$ & & 0.079 & 0.075 & 0.083 \\
\hline partner & $\begin{array}{l}\text { dummy }=1 \text { if respondent has a } \\
\text { partner/spouse }\end{array}$ & 0.699 & 0.685 & 0.709 \\
\hline \multicolumn{5}{|l|}{ Education } \\
\hline compulsory & & 0.11 & 0.094 & 0.123 \\
\hline secondary & & 0.555 & 0.551 & 0.558 \\
\hline tertiary & & 0.335 & 0.355 & 0.319 \\
\hline femaleshare & share of females in & 0.446 & 0.566 & 0.351 \\
\hline & country, year, occupation and firm dimension (large) & (small) & & \\
\hline \multicolumn{5}{|l|}{ Firm and Job characteristics } \\
\hline \multicolumn{5}{|l|}{ Occupation 1-digit ISCO-88 } \\
\hline ISCO 1 - Managers & & 0.055 & 0.041 & 0.066 \\
\hline ISCO 2 - Professionals & & 0.147 & 0.171 & 0.127 \\
\hline ISCO 3 - Technicians & & 0.151 & 0.178 & 0.131 \\
\hline ISCO 4 - Clerks & & 0.134 & 0.209 & 0.075 \\
\hline ISCO 5 - Service workers & & 0.146 & 0.208 & 0.097 \\
\hline ISCO 6 and 7 - Craft \& Trade & & 0.162 & 0.048 & 0.253 \\
\hline ISCO 8 - Plant \& Machinery & & 0.105 & 0.043 & 0.155 \\
\hline ISCO 9 - Elementary occupations & & 0.1 & 0.102 & 0.097 \\
\hline \multicolumn{5}{|l|}{ Industry 1-digit NACE rev.1.1 } \\
\hline Mining and Manufacturing & & 0.225 & 0.154 & 0.282 \\
\hline Electricity, gas, and water supply & & 0.016 & 0.006 & 0.024 \\
\hline Construction & & 0.083 & 0.022 & 0.132 \\
\hline Wholesale and trade & & 0.153 & 0.183 & 0.128 \\
\hline Hotels and restaurants & & 0.038 & 0.046 & 0.032 \\
\hline Transport and communication & & 0.07 & 0.038 & 0.096 \\
\hline Financial intermediation & & 0.037 & 0.041 & 0.035 \\
\hline $\mathrm{RE}$ activities & & 0.067 & 0.067 & 0.068 \\
\hline $\mathrm{PA}$ & & 0.078 & 0.082 & 0.075 \\
\hline Other services & & 0.232 & 0.36 & 0.13 \\
\hline $\ln ($ dimension $)$ & $\log$ of firm size & 3.829 & 3.667 & 3.958 \\
\hline tenure & years in the company & 9.403 & 8.588 & 10.049 \\
\hline pubsector & $\begin{array}{l}\text { dummy }=1 \text { if respondent } \\
\text { works in the public sector }\end{array}$ & 0.283 & 0.355 & 0.225 \\
\hline \multicolumn{5}{|l|}{ Work Organization } \\
\hline \multicolumn{5}{|l|}{ Work Intensity } \\
\hline pace of work & $\begin{array}{l}\text { dummy }=1 \text { if the job involves } \\
\text {-working at high speed }\end{array}$ & 0.617 & 0.576 & 0.649 \\
\hline enough time & $\begin{array}{l}\text {-working with tight deadlines } \\
\text { dummy }=1 \text { if respondent has enough } \\
\text { time to get the job done }\end{array}$ & 0.845 & 0.846 & 0.845 \\
\hline \multicolumn{5}{|l|}{ Time flexibility } \\
\hline long hours & $\begin{array}{l}\text { dummy }=1 \text { if respondent works } \\
->40 \text { hours a week or }\end{array}$ & 0.361 & 0.253 & 0.447 \\
\hline
\end{tabular}

Continues from previous page 


\begin{tabular}{|c|c|c|c|c|}
\hline \multirow[t]{2}{*}{ Variable } & \multirow[t]{2}{*}{ Description } & \multicolumn{3}{|c|}{ Mean } \\
\hline & & All & Females & Males \\
\hline breaks at work & $\begin{array}{l}->10 \text { hours a day at least once a month } \\
\text { dummy }=1 \text { if respondent is able to } \\
\text { take a break when wished }\end{array}$ & 0.587 & 0.55 & 0.615 \\
\hline $\begin{array}{l}\text { Work environment } \\
\text { colleagues support }\end{array}$ & $\begin{array}{l}\text { dummy }=1 \text { if respondent receives } \\
\text { support from collegues }\end{array}$ & 0.899 & 0.891 & 0.905 \\
\hline work-life balance & $\begin{array}{l}\text { dummy }=1 \text { if "well" or "very well" to } \\
\text { Do your working hours fit in with } \\
\text { your family or social commitments? }\end{array}$ & 0.68 & 0.705 & 0.66 \\
\hline partime & $\begin{array}{l}\text { dummy }=1 \text { if respondent works } \\
\text { less than } 30 \text { hours a week }\end{array}$ & 0.141 & 0.257 & 0.049 \\
\hline career advancements & $\begin{array}{l}\text { dummy }=1 \text { if respondent agrees or strongly agrees } \\
\text { with "My job offers good prospects for career advan }\end{array}$ & $\begin{array}{l}0.32 \\
\text { cements" }\end{array}$ & 0.296 & 0.339 \\
\hline riskaversion & $\begin{array}{l}\text { dummy }=1 \text { if respondent always uses } \\
\text { protective equipment when required }\end{array}$ & 0.926 & 0.941 & 0.919 \\
\hline low wage & $\begin{array}{l}\text { dummy }=1 \text { if respondent's wage } \\
\text { lies below median }\end{array}$ & 0.394 & 0.509 & 0.302 \\
\hline satisfaction & $\begin{array}{l}\text { dummy }=1 \text { if respondent is very/satisfied } \\
\text { with working conditions }\end{array}$ & 0.831 & 0.84 & 0.823 \\
\hline Social preferences & dummies $=1$ if respondent involved in & & & \\
\hline voluntary & & 0.067 & 0.061 & 0.072 \\
\hline political & & 0.017 & 0.011 & 0.021 \\
\hline childcaring & & 0.49 & 0.538 & 0.45 \\
\hline sport & & 0.48 & 0.446 & 0.506 \\
\hline \multicolumn{5}{|c|}{ Psycho-social environment } \\
\hline favorable environment & $\begin{array}{l}\text { dummy }=1 \text { if respondent agrees or strongly agrees } \\
\text { - "I feel at home in this organization" } \\
\text { - "I have very good friends at work" }\end{array}$ & 0.84 & 0.839 & 0.841 \\
\hline job security & $\begin{array}{l}\text { dummy }=1 \text { if respondent strongly disagrees, } \\
\text { disagrees or neither agrees nor disagrees with } \\
\text { "I might lose my job in the next } 6 \text { months" }\end{array}$ & 0.837 & 0.844 & 0.832 \\
\hline
\end{tabular}


Table A2 - Gender discrimination and female leadership full specification for Table 2 and Table 3

\begin{tabular}{|c|c|c|c|}
\hline & Whole Sample & Female & Male \\
\hline bosswoman & $\begin{array}{c}-0.183^{* * *} \\
(0.0528)\end{array}$ & $\begin{array}{c}-0.246^{* * *} \\
(0.0564)\end{array}$ & $\begin{array}{l}0.207^{* *} \\
(0.0990)\end{array}$ \\
\hline female & $\begin{array}{c}0.753^{* * *} \\
(0.0612)\end{array}$ & & \\
\hline femaleshare & $\begin{array}{l}-0.0295 \\
(0.194)\end{array}$ & $\begin{array}{l}-0.332 \\
(0.234)\end{array}$ & $\begin{array}{c}0.633^{* *} \\
(0.320)\end{array}$ \\
\hline age $25-35$ & $\begin{array}{c}0.0142 \\
(0.0762)\end{array}$ & $\begin{array}{l}-0.0354 \\
(0.0914)\end{array}$ & $\begin{array}{c}0.157 \\
(0.131)\end{array}$ \\
\hline age $36-55$ & $\begin{array}{l}-0.0175 \\
(0.0793)\end{array}$ & $\begin{array}{l}-0.0656 \\
(0.0939)\end{array}$ & $\begin{array}{c}0.111 \\
(0.148)\end{array}$ \\
\hline age $56+$ & $\begin{array}{c}-0.432^{* * *} \\
(0.117)\end{array}$ & $\begin{array}{c}-0.482^{* * *} \\
(0.135)\end{array}$ & $\begin{array}{l}-0.341 \\
(0.256)\end{array}$ \\
\hline partner & $\begin{array}{c}-0.140^{* * *} \\
(0.0444)\end{array}$ & $\begin{array}{c}-0.130^{* *} \\
(0.0510)\end{array}$ & $\begin{array}{c}-0.128 \\
(0.0900)\end{array}$ \\
\hline secondary educ & $\begin{array}{c}-0.100 \\
(0.0787)\end{array}$ & $\begin{array}{r}-0.0737 \\
(0.100)\end{array}$ & $\begin{array}{l}-0.148 \\
(0.132)\end{array}$ \\
\hline tertiary educ & $\begin{array}{c}-0.0678 \\
(0.0893)\end{array}$ & $\begin{array}{c}0.00375 \\
(0.114)\end{array}$ & $\begin{array}{c}-0.303^{* *} \\
(0.140)\end{array}$ \\
\hline $\ln ($ dimension $)$ & $\begin{array}{c}0.0407^{* * *} \\
(0.0143)\end{array}$ & $\begin{array}{c}0.0253 \\
(0.0163)\end{array}$ & $\begin{array}{c}0.0864^{* * * *} \\
(0.0278)\end{array}$ \\
\hline tenure & $\begin{array}{l}-0.00327 \\
(0.00287)\end{array}$ & $\begin{array}{l}-0.00288 \\
(0.00344)\end{array}$ & $\begin{array}{l}-0.00244 \\
(0.00532)\end{array}$ \\
\hline public sector & $\begin{array}{c}0.0790 \\
(0.0628)\end{array}$ & $\begin{array}{c}0.0674 \\
(0.0734)\end{array}$ & $\begin{array}{l}0.0757 \\
(0.119)\end{array}$ \\
\hline pace of work & $\begin{array}{c}0.193^{* * *} \\
(0.0522)\end{array}$ & $\begin{array}{c}0.157^{* * *} \\
(0.0598)\end{array}$ & $\begin{array}{c}0.319^{* * *} \\
(0.0996)\end{array}$ \\
\hline enough time & $\begin{array}{c}-0.195^{* * *} \\
(0.0514)\end{array}$ & $\begin{array}{c}-0.180^{* * *} \\
(0.0652)\end{array}$ & $\begin{array}{c}-0.240^{* * *} \\
(0.0803)\end{array}$ \\
\hline long hours & $\begin{array}{c}0.193^{* * *} \\
(0.0484)\end{array}$ & $\begin{array}{c}0.274^{* * *} \\
(0.0568)\end{array}$ & $\begin{array}{c}0.0518 \\
(0.0867)\end{array}$ \\
\hline breaks at work & $\begin{array}{c}-0.168^{* * *} \\
(0.0437)\end{array}$ & $\begin{array}{c}-0.193^{* * *} \\
(0.0523)\end{array}$ & $\begin{array}{l}-0.0915 \\
(0.0778)\end{array}$ \\
\hline colleagues support & $\begin{array}{l}-0.0983 \\
(0.0600)\end{array}$ & $\begin{array}{l}-0.128^{*} \\
(0.0717)\end{array}$ & $\begin{array}{c}-0.0260 \\
(0.120)\end{array}$ \\
\hline work-life balance & $\begin{array}{c}-0.363^{* * *} \\
(0.0538)\end{array}$ & $\begin{array}{c}-0.412^{* * *} \\
(0.0636)\end{array}$ & $\begin{array}{c}-0.273^{* * *} \\
(0.0948)\end{array}$ \\
\hline constant & $\begin{array}{c}-2.155^{* * *} \\
(0.222)\end{array}$ & $\begin{array}{c}-1.119^{* * *} \\
(0.253)\end{array}$ & $\begin{array}{c}-2.738^{* * * *} \\
(0.442)\end{array}$ \\
\hline Industry and occupation & $\checkmark$ & $\checkmark$ & $\checkmark$ \\
\hline Country and Year Dummies & $\checkmark$ & $\checkmark$ & $\checkmark$ \\
\hline $\begin{array}{l}\text { pseudo- } R^{2} \\
\mathrm{~N}\end{array}$ & $\begin{array}{l}0.1216 \\
63,318\end{array}$ & $\begin{array}{l}0.0965 \\
31,637\end{array}$ & $\begin{array}{l}0.1356 \\
30,624\end{array}$ \\
\hline
\end{tabular}

$* \mathrm{p}<0.1,{ }^{* *} \mathrm{p}<0.05,{ }^{* * *} \mathrm{p}<0.01 ;$ robust standard errors in parentheses. Empirical specification as in Table 2, column 4 . 
Table A3 - Full specification for Table 2 and Table 3 (marginal effects)

\begin{tabular}{|c|c|c|c|}
\hline & Whole Sample & Female & Male \\
\hline bosswoman & $\begin{array}{c}-0.635^{* * *} \\
(0.174)\end{array}$ & $\begin{array}{c}-1.445 * * * \\
(0.321)\end{array}$ & $\begin{array}{l}0.391^{*} \\
(0.217)\end{array}$ \\
\hline female & $\begin{array}{c}2.802^{* * *} \\
(0.260)\end{array}$ & & \\
\hline femaleshare & $\begin{array}{l}-0.109 \\
(0.720)\end{array}$ & $\begin{array}{l}-2.050 \\
(1.46)\end{array}$ & $\begin{array}{l}1.009 * \\
(0.522)\end{array}$ \\
\hline age $25-35$ & $\begin{array}{l}0.0526 \\
(0.282)\end{array}$ & $\begin{array}{l}-0.219 \\
(0.566)\end{array}$ & $\begin{array}{c}0.250 \\
(0.209)\end{array}$ \\
\hline age $36-55$ & $\begin{array}{r}-0.0649 \\
(0.294)\end{array}$ & $\begin{array}{l}-0.405 \\
(0.582)\end{array}$ & $\begin{array}{c}0.178 \\
(0.234)\end{array}$ \\
\hline age $56+$ & $\begin{array}{c}-1.603^{* * *} \\
(0.448)\end{array}$ & $\begin{array}{c}-2.978^{* * *} \\
(0.867)\end{array}$ & $\begin{array}{l}-0.544 \\
(0.418)\end{array}$ \\
\hline partner & $\begin{array}{c}-0.518^{* * *} \\
(0.164)\end{array}$ & $\begin{array}{c}-0.805^{* *} \\
(0.315)\end{array}$ & $\begin{array}{l}-0.205 \\
(0.143)\end{array}$ \\
\hline secondary educ & $\begin{array}{l}-0.372 \\
(0.292)\end{array}$ & $\begin{array}{l}-0.455 \\
(0.619)\end{array}$ & $\begin{array}{l}-0.236 \\
(0.214)\end{array}$ \\
\hline tertiary educ & $\begin{array}{l}-0.251 \\
(0.332)\end{array}$ & $\begin{array}{l}0.0232 \\
(0.707)\end{array}$ & $\begin{array}{c}-0.483^{* *} \\
(0.229)\end{array}$ \\
\hline $\ln ($ dimension $)$ & $\begin{array}{l}0.151^{* * *} \\
(0.0534)\end{array}$ & $\begin{array}{c}0.156 \\
(0.101)\end{array}$ & $\begin{array}{c}0.138^{* * *} * \\
(0.0478)\end{array}$ \\
\hline tenure & $\begin{array}{l}-0.0121 \\
(0.0106)\end{array}$ & $\begin{array}{l}-0.0178 \\
(0.0212)\end{array}$ & $\begin{array}{l}-0.00389 \\
(0.00846)\end{array}$ \\
\hline public sector & $\begin{array}{c}0.293 \\
(0.234)\end{array}$ & $\begin{array}{c}0.416 \\
(0.454)\end{array}$ & $\begin{array}{c}0.121 \\
(0.190)\end{array}$ \\
\hline pace of work & $\begin{array}{c}0.669^{* * *} \\
(0.169)\end{array}$ & $\begin{array}{c}0.929 * * * \\
(0.334)\end{array}$ & $\begin{array}{c}0.441^{* * *} \\
(0.126)\end{array}$ \\
\hline enough time & $\begin{array}{c}-0.807^{* * *} \\
(0.236)\end{array}$ & $\begin{array}{c}-1.223^{* *} \\
(0.484)\end{array}$ & $\begin{array}{c}-0.446^{* * *} \\
(0.172)\end{array}$ \\
\hline long hours & $\begin{array}{c}0.753^{* * *} \\
(0.199)\end{array}$ & $\begin{array}{c}1.867^{* * * *} \\
(0.427)\end{array}$ & $\begin{array}{c}0.0826 \\
(0.139)\end{array}$ \\
\hline breaks at work & $\begin{array}{c}-0.631^{* * *} \\
(0.169)\end{array}$ & $\begin{array}{c}-1.199 * * * \\
(0.335)\end{array}$ & $\begin{array}{l}-0.148 \\
(0.128)\end{array}$ \\
\hline colleagues support & $\begin{array}{l}-0.393 \\
(0.255)\end{array}$ & $\begin{array}{c}-0.860^{*} \\
(0.520)\end{array}$ & $\begin{array}{c}-0.0425 \\
(0.201)\end{array}$ \\
\hline work-life balance & $\begin{array}{c}-1.487^{* * *} \\
(0.249)\end{array}$ & $\begin{array}{c}-2.844^{* * *} \\
(0.505)\end{array}$ & $\begin{array}{c}-0.473^{* * *} \\
(0.181)\end{array}$ \\
\hline constant & $\begin{array}{c}-2.146 * * * \\
(0.222)\end{array}$ & $\begin{array}{c}-1.108 * * * \\
(0.252)\end{array}$ & $\begin{array}{c}-2.729 * * * \\
(0.446)\end{array}$ \\
\hline Industry and occupation & $\checkmark$ & $\checkmark$ & $\checkmark$ \\
\hline Country and Year Dummies & $\checkmark$ & $\checkmark$ & $\checkmark$ \\
\hline pseudo- $R^{2}$ & 0.1216 & 0.0965 & 0.1356 \\
\hline $\mathrm{N}$ & 63,318 & 31,637 & 30,624 \\
\hline
\end{tabular}

${ }^{*} \mathrm{p}<0.1,{ }^{* *} \mathrm{p}<0.05,{ }^{* * *} \mathrm{p}<0.01$; robust standard errors in parentheses. Empirical specification as in Table 2, column 4.

Marginal effects and standard errors are multiplied by 100 . 
Table A4 - Robustness checks (reporting bias on female sample)

\begin{tabular}{|c|c|c|c|}
\hline & \multicolumn{3}{|c|}{ Perceived discrimination } \\
\hline & Age & Race & Nationality \\
\hline bosswoman & $\begin{array}{c}0.0369 \\
(0.0537)\end{array}$ & $\begin{array}{l}0.202^{* *} \\
(0.0864)\end{array}$ & $\begin{array}{c}0.145^{*} \\
(0.0795)\end{array}$ \\
\hline femaleshare & $\begin{array}{c}0.125 \\
(0.255)\end{array}$ & $\begin{array}{c}-0.0809 \\
(0.316)\end{array}$ & $\begin{array}{l}-0.177 \\
(0.321)\end{array}$ \\
\hline constant & $\begin{array}{c}-1.183^{* * *} \\
(0.273)\end{array}$ & $\begin{array}{c}-1.784^{* * *} \\
(0.372)\end{array}$ & $\begin{array}{c}-2.144^{* * *} \\
(0.346)\end{array}$ \\
\hline \multirow{4}{*}{$\begin{array}{l}\text { pseudo- } R^{2} \\
\mathrm{~N}\end{array}$} & 0.0855 & 0.1060 & 0.1152 \\
\hline & 30,517 & 30,517 & 30,517 \\
\hline & \multicolumn{3}{|c|}{ Placebo test on other subjective measures } \\
\hline & & $\begin{array}{c}\text { Health safety } \\
\text { Risk }\end{array}$ & $\begin{array}{c}\text { Work affects } \\
\text { Health }\end{array}$ \\
\hline bosswoman & & $\begin{array}{l}-0.0139 \\
(0.0305)\end{array}$ & $\begin{array}{l}0.00880 \\
(0.0273)\end{array}$ \\
\hline femaleshare & & $\begin{array}{l}0.0748 \\
(0.137)\end{array}$ & $\begin{array}{l}0.0332 \\
(0.125)\end{array}$ \\
\hline constant & & $\begin{array}{c}-0.537^{* * *} \\
(0.153)\end{array}$ & $\begin{array}{l}0.0606 \\
(0.141)\end{array}$ \\
\hline pseudo- $R^{2}$ & & 0.1177 & 0.1481 \\
\hline $\mathrm{N}$ & & 30,517 & 30,517 \\
\hline
\end{tabular}

$* \mathrm{p}<0.1, * * \mathrm{p}<0.05, * * * \mathrm{p}<0.01$; robust standard errors in parentheses. Empirical specification as in Table 2, column 4. 
Table A5 - Robustness checks (country-clusters)

\begin{tabular}{|c|c|c|c|c|}
\hline & \multicolumn{2}{|c|}{ Estimated coefficients } & \multirow{2}{*}{$\begin{array}{l}\text { Wald- } \chi^{2} \\
(p \text {-value })\end{array}$} & \multirow[t]{2}{*}{ Obs. } \\
\hline & Bosswoman & Female & & \\
\hline Nordic & $\begin{array}{c}-0.199 * * \\
(0.095)\end{array}$ & $\begin{array}{c}0.792^{* * *} \\
(0.123)\end{array}$ & $\begin{array}{l}214.07 \\
(0.000)\end{array}$ & 9,371 \\
\hline Continental & $\begin{array}{c}-0.214^{* * *} \\
(0.076)\end{array}$ & $\begin{array}{c}0.857^{* * *} \\
(0.098)\end{array}$ & $\begin{array}{l}295.84 \\
(0.000)\end{array}$ & 19,515 \\
\hline Mediterranean & $\begin{array}{c}-0.204^{*} \\
(0.123)\end{array}$ & $\begin{array}{c}0.767^{* * * *} \\
(0.116)\end{array}$ & $\begin{array}{l}184.12 \\
(0.000)\end{array}$ & 9,664 \\
\hline Anglosaxons & $\begin{array}{l}-0.155 \\
(0.143)\end{array}$ & $\begin{array}{c}0.929^{* * *} \\
(0.176)\end{array}$ & $\begin{array}{l}181.34 \\
(0.000)\end{array}$ & 5,763 \\
\hline Baltic & $\begin{array}{c}-0.421^{* *} \\
(0.181)\end{array}$ & $\begin{array}{c}0.766^{* * * *} \\
(0.251)\end{array}$ & $\begin{array}{l}558.38 \\
(0.000)\end{array}$ & 3,164 \\
\hline East EU/North & $\begin{array}{c}-0.572^{* * *} \\
(0.124)\end{array}$ & $\begin{array}{c}0.879 * * * \\
(0.179)\end{array}$ & $\begin{array}{l}131.32 \\
(0.000)\end{array}$ & 8,635 \\
\hline East EU/South & $\begin{array}{c}0.113 \\
(0 . .189)\end{array}$ & $\begin{array}{c}0.392 * * \\
(0.186)\end{array}$ & $\begin{array}{l}156.98 \\
(0.000)\end{array}$ & 2,811 \\
\hline
\end{tabular}

$* \mathrm{p}<0.1$, ** $\mathrm{p}<0.05$, *** $\mathrm{p}<0.01$; robust standard errors in parentheses. Empirical specification as in Table 2, column 4. 